\title{
Mafic intrusions on Campobello Island: implications for New Brunswick - Maine correlations
}

\author{
Malcolm J. McLeod ${ }^{1}$, Ron K. Pickerill ${ }^{2}$, and R. Dan Lux ${ }^{3}$ \\ ${ }^{\prime}$ New Brunswick Department of Natural Resources and Energy, Geological Surveys Branch, \\ P.O. Box 5040, Sussex New Brunswick E4E 5L2 \\ ${ }^{2}$ Department of Geology, University of New Brunswick, P.O. Box 4400, Fredericton, New \\ Brunswick E3B 5A3 \\ ${ }^{3}$ Department of Geological Sciences, University of Maine in Orono, 168 College Avenue, \\ Orono, Maine 04469, U.S.A.
}

Date Received: May 17, 2001

Date Accepted: December 7, 2001

\begin{abstract}
Late Ordovician through Early Devonian units of the Passamaquoddy Bay area are interpreted to represent sequences that evolved in arc and back-arc environments. The main elements of the arc are exposed on Campobello Island and include a predominantly felsic volcanic sequence to the northeast, a sequence of intercalated turbidite and mafic volcanic rocks to the southwest, and mafic dyke swarms throughout. Petrographic, geochemical, and ${ }^{40} \mathrm{Ar} /{ }^{39} \mathrm{Ar}$ studies of these rocks record episodic deformation and varying degrees of metamorphism up to lower amphibolite facies, and a protracted history of mafic magma injection from a similar source beginning in the Early Silurian. These features, combined with stratigraphic relationships and overall structural patterns, indicate a rapid transition from felsic- to mafic-dominated magmatism accompanied by radical changes in the depositional regime in the arc with time, and exposure of progressively deeper crustal levels towards the northeast within the arc.

Review of the assignment of other units in the Passamaquoddy Bay region to major tectonostratigraphic belts north of Campobello Island clarifies regional correlations and provides possible additional links to Neoproterozoic basement in the area.
\end{abstract}

Les unités de l'Ordovicien supérieur au Dévonien inférieur du secteur de la baie Passamaquoddy sont interprétées comme des unités représentatives de séquences ayant évolué dans des environnements d'arc et d'arrière-arc. Les principaux éléments de l'arc affleurent sur l'île Campobello et comportent une séquence principalement volcanofelsique au nord-est, une séquence volcanomafique/turbiditique intercalée au sud-ouest et des groupes de filons mafiques un peu partout. Des études pétrographiques, géochimiques et ${ }^{40} \mathrm{Ar} /{ }^{39} \mathrm{Ar}$ de ces roches relèvent une déformation épisodique et des degrés divers de métamorphisme jusqu'au faciès amphibolique inférieur, ainsi que des antécédents prolongés d'injection de magma mafique d'une source similaire à partir du Silurien inférieur. Ces particularités, conjuguées aux relations stratigraphiques et aux configurations structurales générales, révèlent une transition rapide d'un magmatisme à prédominance felsique à un magmatisme à prédominance mafique accompagné de changements spectaculaires dans le régime de sédimentation à l'intérieur de l'arc avec le temps, ainsi qu'un affleurement de niveaux crustaux progressivement plus profonds vers le nord-est à l'intérieur de l'arc.

L'examen de l'affectation des autres unités dans la région de la baie Passamaquoddy aux principales structures teconostratigraphiques au nord de l'île Campobello clarifie les corrélations régionales et fournit des liens supplémentaires possibles avec le socle du Protérozoïque supérieur du secteur.

Traduit par la rédaction

\section{INTRODUCTION}

Diabase dykes and gabbroic intrusions comprise a significant portion of most Silurian sections in the Passamaquoddy Bay area of southwestern New Brunswick. Numerous older publications based on work in the 1960s and 1970s (e.g., Cumming 1966; Helmstaedt 1968; Ruitenberg 1968; Donohoe 1978; Gates 1969; Pickerill et al. 1978; Ruitenberg and McCutcheon 1982; McLeod and Rast 1988) and a few papers referring to more recent work (e.g., Berry and Osberg 1989; Fyffe et al. 1999) described the stratigraphy and structure of stratified rocks of the area, made regional correlations, and addressed their tectonic significance. Few, however, provided comprehensive information on the mafic intrusions that are also considered useful in unravelling the tectonic history of the region and help to confirm regional correlations. These intrusions are particularly abundant and well exposed on Campobello Island, located at the entrance to Passamaquoddy Bay along the Maine-New Brunswick border (Fig. 1).

Previously unpublished information pertaining to the mafic intrusions, including geochemistry and ${ }^{40} \mathrm{Ar} /{ }^{39} \mathrm{Ar}$ data, and stratigraphic relationships between major sequences on Campobello Island, is presented here. These data, combined with newly acquired information from similar sequences along strike and recent mapping programs around Passamaquoddy 


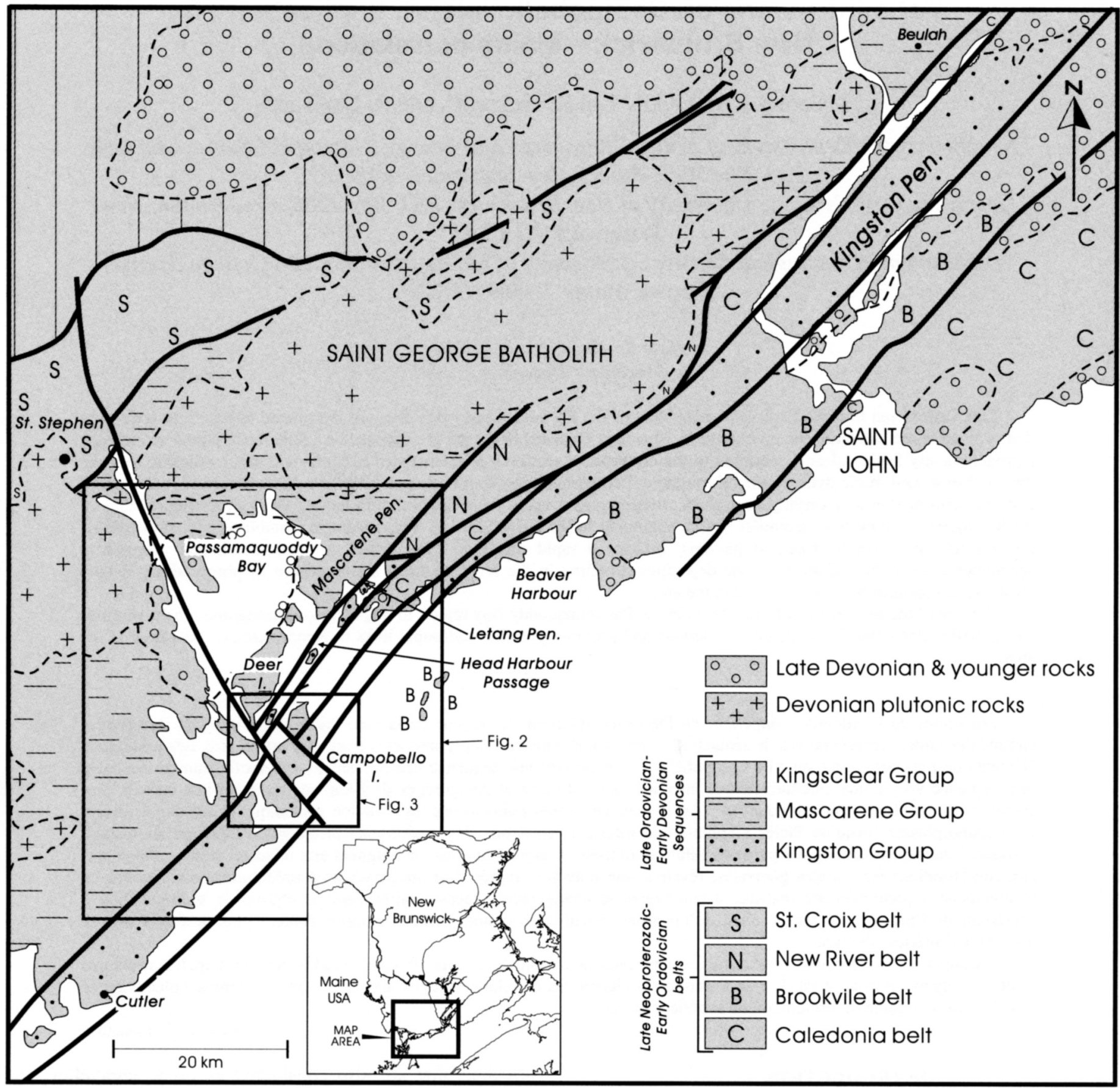

Fig. 1. Regional geology of southwestern New Brunswick and southeastern Maine. Terranes bounding the Kingston Belt to the northwest modified after Johnson (2001).

Bay, provide insight into the tectonic development of the area and clarify detailed correlations in the region.

\section{GEOLOGICAL SETTING, HISTORICAL PERSPECTIVE, AND TERMINOLOGY}

Late Ordovician through Early Devonian sequences in southwestern New Brunswick and southeastern Maine were deposited within and along the margins of exposed Neoproterozoic peri-Gondwanan terranes to the southeast (the
New River and Brookville belts of Johnson and McLeod (1996) and Barr and White (1989) and the remnants of their sedimentary apron to the northwest (the St. Croix belt of Fyffe and Fricker (1987)) (Fig. 1). The Late Ordovician to Early Devonian sequences around Passamaquoddy Bay are distributed among several fault-bounded, lithotectonically distinct belts commonly referred to informally as the Ovenhead, Mascarene and Kingston belts (Ruitenberg and McCutcheon 1982; McLeod and Rast 1988) (Fig. 2).

Traditionally, the Ovenhead belt has been considered to 

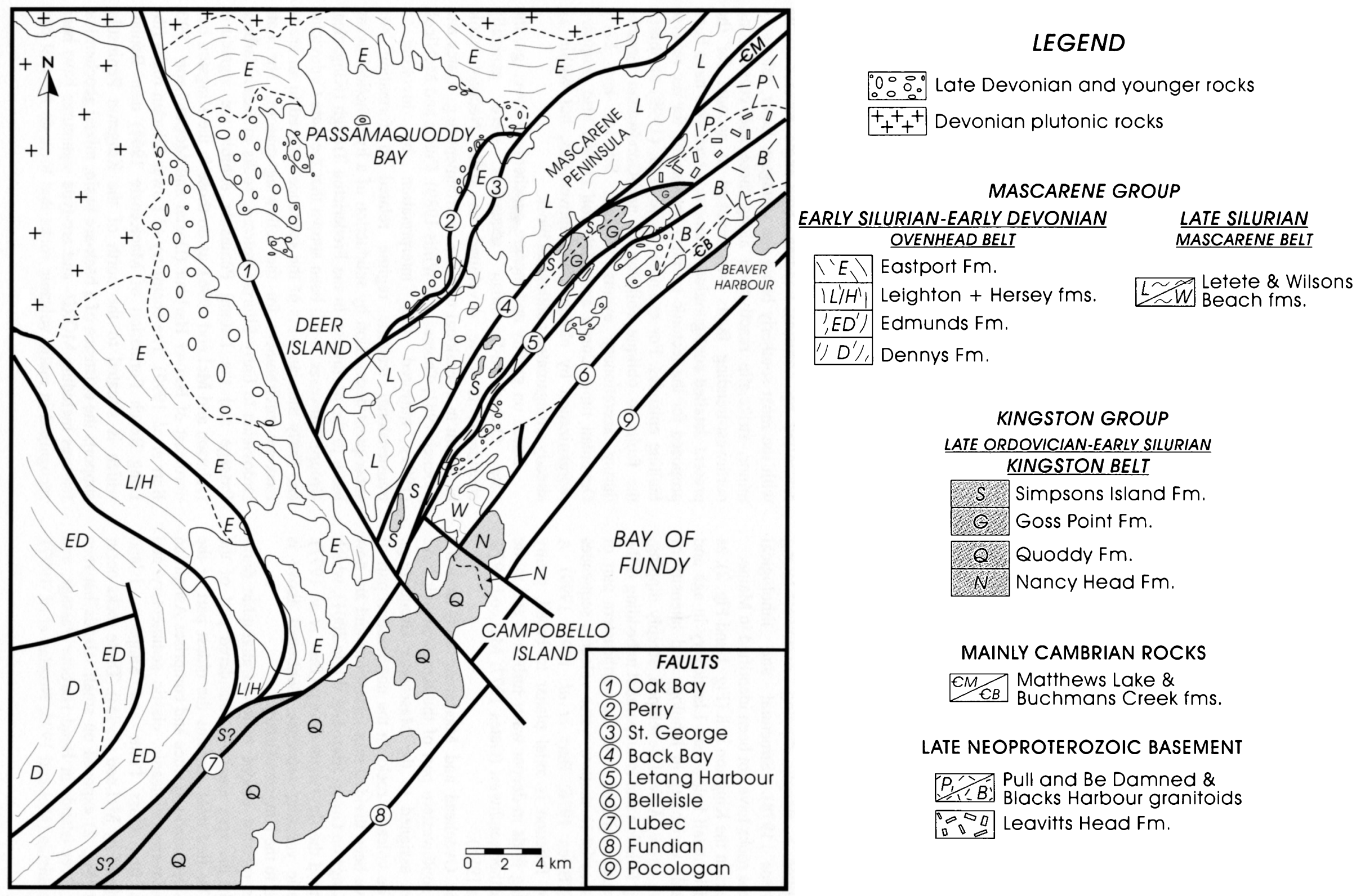

\section{KINGSTON GROUP}

LATE ORDOVICIAN-EARLY SILURIAN KINGSTON BELT

\begin{tabular}{|c|c|}
\hline$S$ & Simpsons Island Fm. \\
\hline$G$ & Goss Point Fm. \\
\hline Q & Quoddy Fm. \\
\hline N & Nancy Head Fm. \\
\hline
\end{tabular}

MAINLY CAMBRIAN ROCKS

CM Matthews Lake \&

$C B$ Buchmans Creek fms.

\section{LATE NEOPROTEROZOIC BASEMENT}

$P^{\prime \prime}$ Pull and Be Damned \& P.: B: Blacks Harbour granitoids .

Fig. 2. Distribution of major lithotectonic belts in the Passamaquoddy Bay region. Maine geology after Gates (1984) 
occur only south of the Saint George Batholith (Fig. 1 and Fig. 2). In general, it contains a continuous depositional sequence with shallow water Wenlockian to Pridolian rocks at the base overlain by intertidal to subaerial Lochovian units (e.g., Gates 1977; Pickerill et al. 1976; Pickerill et al. 1978; Fyffe et al. 1999). Structurally, the belt is characterized by a single poorto well-developed cleavage that is coplanar to non-coplanar with a broad, gently east-plunging anticlinal and a shallowly north-plunging synclinal folds defined by shallowly dipping units (Ruitenberg 1968; Gates 1977; McLeod and Rast 1988; Van Wagoner et al. 1994). A faulted, moderately southeastdipping homoclinal sequence occurs north of the Saint George Batholith and contains Ludlovian and Pridolian units (Fyffe $e t$ al. 1999). This sequence dips moderately towards the southeast and exhibits a single, poorly- to moderately-well developed, steeply dipping cleavage that strikes northeast. Based on paleontological data and on overall lithological and structural features presented by Fyffe et al. (1999), the homoclinal sequence can be considered a faulted segment of the upper part of the Ovenhead belt (L. Fyffe, personal communication 2001).

In contrast, the Mascarene belt comprises a structurally complex shallow water volcano-sedimentary sequence of mostly Pridolian age, typified by northeast-trending, polydeformed units (Ruitenberg 1968; Donohoe 1978). Overall, this belt constitutes a steeply dipping, northwest-facing sequence (Donohoe 1978). Structural and lithological equivalents of these rocks have not been identified in Maine.

Stratified rocks in the Kingston belt (Fig. 1 and Fig. 2), as will be discussed in detail below, are Llandovery in age and exhibit considerable variability in lithology and intensity of deformation along strike. A well developed, steeply dipping, northeast-trending foliation that is subparallel to bedding is the most prominent structural feature in the northeastern part of the belt where subaerial to shallow water volcanic sequences are prevalent (O'Brien 1976; Barr et al. 1997, 1999). A similarly oriented foliation is axial planar to broad, gently southwest-plunging folds in deeper water turbiditic and mafic volcanic rocks farther southwest (Gates 1977; McLeod 1979; McLeod and Rast 1988).

Rocks in the Ovenhead and Mascarene belts and the turbidites in the southwestern part of the Kingston belt have traditionally been assigned to the Mascarene Group (e.g., Alcock 1949). The volcanic rocks in the northeastern part of the latter belt have been divided into formations and are now assigned to the Kingston Group (Barr and White 2001), which was formerly termed the Bayswater Group (Barr et al. 1997). The turbidite/mafic volcanic sequence mentioned above is now also assigned to the Kingston Group.

Two other somewhat unique tectonostratigraphic faultbounded tracts in the area are now considered part of the Kingston belt. The first tract contains the oldest part of the Late Ordovician-Devonian sequence and comprises Ashgillian to possibly Llandoverian volcanic, clastic sedimentary and carbonate rocks (the Goss Point and Simpsons Island formations as defined by McLeod (1995)). These rocks occur in a narrow belt (Fig. 2) exposed on small islands between Campobello and Deer islands in Head Harbour Passage, and on the Letang Peninsula (McLeod 1995; Nowlan et al. 1997).
In general, they are structurally simple like those in the southwestern part of the Kingston belt and exhibit arc-type geochemical signatures. The second tract contains units bounded by splays of the Lubec Fault zone, north of the main outcrop of the Quoddy Formation in Maine. This tract was tentatively assigned an Early Devonian age based on gross lithological correlations of constituent volcanic units with other volcanic units of known age in the region (Gates 1977). However, similar volcanic rocks are present in the Ashgillian to possibly Landoverian tract mentioned above that are nearly along strike. We therefore postulate that these two tracts are equivalent as suggested by L. Fyffe (personal communication 2001).

Previously, workers in the Passamaquoddy Bay area have regarded the volcano-sedimentary rocks in these belts, in general, as representing more or less conformable sequences developed in an extensional marine basin gradually shallowing from deeper water (below wavebase) to intertidal and subaerial environments (Gates 1977; Pickerill et al. 1978). McLeod and Rast (1988) highlighted the structural and lithological contrasts between the major belts and, because of these contrasts, proposed deposition and deformation in separate parts of the large extensional basin (or basins) and subsequent juxtaposition by protracted faulting. They considered the present configuration of the belts to be largely controlled by northeast-trending, high-angle reverse faults with the most southerly being the youngest. Later, relatively minor, strike-slip reactivation along these and crosscutting northwest-trending faults was invoked to account for the present detailed configuration. Numerous scenarios have been proposed for the tectonic event(s) responsible for the reverse faulting episodes. For example, Fyffe et al. (1999) attributed the faults to oblique collision of peri-Gondwanan terranes during accretionary events in Late Silurian and Early Devonian time. Currie and McNicoll (1999) also proposed reorganization by oblique fault movements, but within an already amalgamated continental block.

Based on gravity and meagre geochemical coverage, the Late Ordovician-Devonian sequences were generally considered to have developed on sialic Neoproterozoic basement in a tensional tectonic environment (e.g., Gates and Moench 1981; Thomas and Willis 1989). Currie and McNicoll (1999) mirrored this interpretation by invoking a transtensional tectonic regime related to formation and subsequent destruction by subduction of a hypothetical ocean basin to the northwest, in the Fredericton Trough (Kingsclear Group). However, it has been shown that the Late Ordovician and Early Silurian parts of the sequence evolved in an arc to back-arc environment for the following reasons. The Late Ordovician to Early Silurian volcanic rocks in Head Harbour Passage and the Letang Peninsula exhibit arc signatures (Johnson and McLeod 1996), as do those in the Kingston belt northeast of Beaver Harbour (Dostal and McCutcheon 1990; Barr et al. 1999). The chemistry of Lower Silurian rocks (the Long Reach Formation of MacKenzie 1964) near Beulah, which is situated to the north of the Kingston Peninsula, supports the existence of a back-arc basin; mixed geochemical features including MORB- and arc-type signatures have been recognized in mafic volcanic rocks that form an integral part 
of the cover sequence in this area (McLeod 1997; McLeod and Pickerill 1999).

Diabase dyke swarms, prolific throughout the Kingston belt, are generally thought to indicate period(s) of extension that developed within an overall transtensional (Eby and Currie 1993; Currie and McNicoll 1999) or transpressional (Rast and Dickson 1982; Dickson 1983; Nance and Dallmeyer 1993) environment during which the host rocks of the dikes in the Kingston Group formed. Published chemical data on the dykes indicates formation in a within-plate setting, but with a continental margin or arc signature (Eby and Currie 1993; Barr et al. 1999). The source of contamination producing the subduction zone imprint on the dykes has been attributed either to Late Neoproterozoic arc-type basement (Eby and Currie 1993) or to the intruded Early Silurian volcanic pile itself (Barr et al. 1999).

The proposed Early Silurian arc represented by the Kingston Group, termed the "Kingston Arc" by Fyffe et al. (1999), is thought to have evolved on ensialic crust above a northward-dipping subduction zone along the southern margin of the New River belt (Fyffe et al. 1999). These authors included the Brookville belt of Barr and White (1989) in this continental block. Fyffe et al. (1999) further suggested that the term "Mascarene Basin" be used in reference to the depositional centre for the remainder of the Siluro-Devonian sequences to the north of the arc, and that it represented the back-arc basin. The intraplate tholeiitic signature exhibited by the Late Silurian and Early Devonian volcanic rocks in the northern part of the basin (Gates and Moench 1981; Baldwin 1991; Fyffe, unpublished data, personal communication) is consistent with extrusion in a back-arc setting becoming more continental in character with time (Currie and McNicoll 1999; Fyffe et al. 1999).

\section{STRATIGRAPHY AND STRUCTURE, CAMPOBELLO ISLAND}

\section{Introduction}

The southwesternmost Silurian rocks of the Late Ordovician-Early Devonian sequences in the Passamaquoddy Bay region are exposed on Campobello Island (Fig. 3). Three lithotectonic units are present and include a shallow subaqueous to subaerial felsic volcanic sequence, a deeper water mainly turbiditic sedimentary and mafic volcanic succession, and a unit of intercalated sedimentary and felsic volcanic rocks deposited in a shallow water environment (McLeod 1979; McLeod and Rast 1988). These rocks are assigned to the Nancy Head (new name), Quoddy (Bastin and Williams 1914) and Wilsons Beach (herein modified after McLeod 1979) formations, respectively. Cumming (1966) first recognized that the Nancy Head Formation correlates with similar rocks in the Kingston belt to the northeast. At that time, these were thought to be correlatives of the Neoproterozoic Coldbrook Group (Alcock 1938). Cumming (1966) also realized that the mainly turbiditic and mafic volcanic succession was the northeastward continuation of the Lower Silurian Quoddy Formation in Maine. McLeod (1979) and McLeod and Rast (1988) later confirmed this interpretation and recognized that the voluminous gabbro and diabase intrusions of the Cutler Diabase that intrude the Quoddy Formation in Maine (Gates 1961, 1977) outcrop on Campobello Island. Furthermore, they suggested that the Wilsons Beach Formation could be correlative with the Late Silurian (Pridolian) Letete Formation (Donohoe 1978) on the Mascarene Peninsula and Deer Island north of Campobello Island. Essentially, the Wilsons Beach Formation is thought to represent the southern extension of the Mascarene belt on Deer Island juxtaposed against the Kingston belt by minor reactivation of major, northeast-trending faults (McLeod and Rast 1988).

\section{Nancy Head Formation}

The Nancy Head Formation comprises the northeastern part of Campobello Island and is bounded by the Belleisle Fault to the northwest and by the Schooner Cove Fault and the Quoddy Formation to the southwest (Fig. 3). The unit is best exposed along the shore at Nancy Head and in coves north and south of this locality. Due to intense diabase dyking, deformation and recrystallisation, establishment of the local stratigraphy is difficult and the thickness of the formation could not be established. The formation is cut by the northwest-trending Schooner Cove Fault, an oblique-slip fault that exhibits a normal component of southwest-side-down movement. This fault is interpreted to be the ancestral trace of the Oak Bay Fault, displaced by minor dextral strike-slip movement along the Letang Harbour fault zone (McLeod and Rast 1988).

The formation is mainly composed of intercalated units dominated by light to dark grey and pink to tan felsic volcanic and volcanogenic sedimentary rocks, all of which are intruded by numerous mafic dykes. Siliceous, and very minor mafic, fine- to coarse-grained lithic- and/or crystal-rich tuff, lapilli tuff and breccia are the most common rock types. Primary depositional features are poorly preserved due mainly to intense recrystallisation. Where these features are preserved, coarse-grained rock types occur in thick beds and, in places, exhibit large-scale cross-bedding, parallel lamination, and normal grading. The finer-grained rock types are mostly thinly bedded and are normally graded (locally) or exhibit truncated ripple structures (Fig. 4a). These features and the presence of arcuate flaser-like fragments of siltstone in some beds indicate significant local reworking of the volcanic debris. The remainder of the formation comprises intensely recrystallized, black aphanitic siliceous rocks that contain faint pink to grey siliceous blotches (relict fragments) up to $5 \mathrm{~cm}$ in length, which are probably siliceous lapilli. Rare, semi-continuous bands that exhibit contrasting sizes of these fragments likely represent bedding.

Structurally, the Nancy Head Formation is affected by a single, well-defined, steeply dipping and northeast-trending schistosity with locally developed, steeply plunging mineral and clast lineations. Incipient crenulations of this fabric are widely developed, but are typically observable only in thin section. In zones with prolific mafic dykes (common in this unit), it is apparent that dyke injection has rotated shallowly 


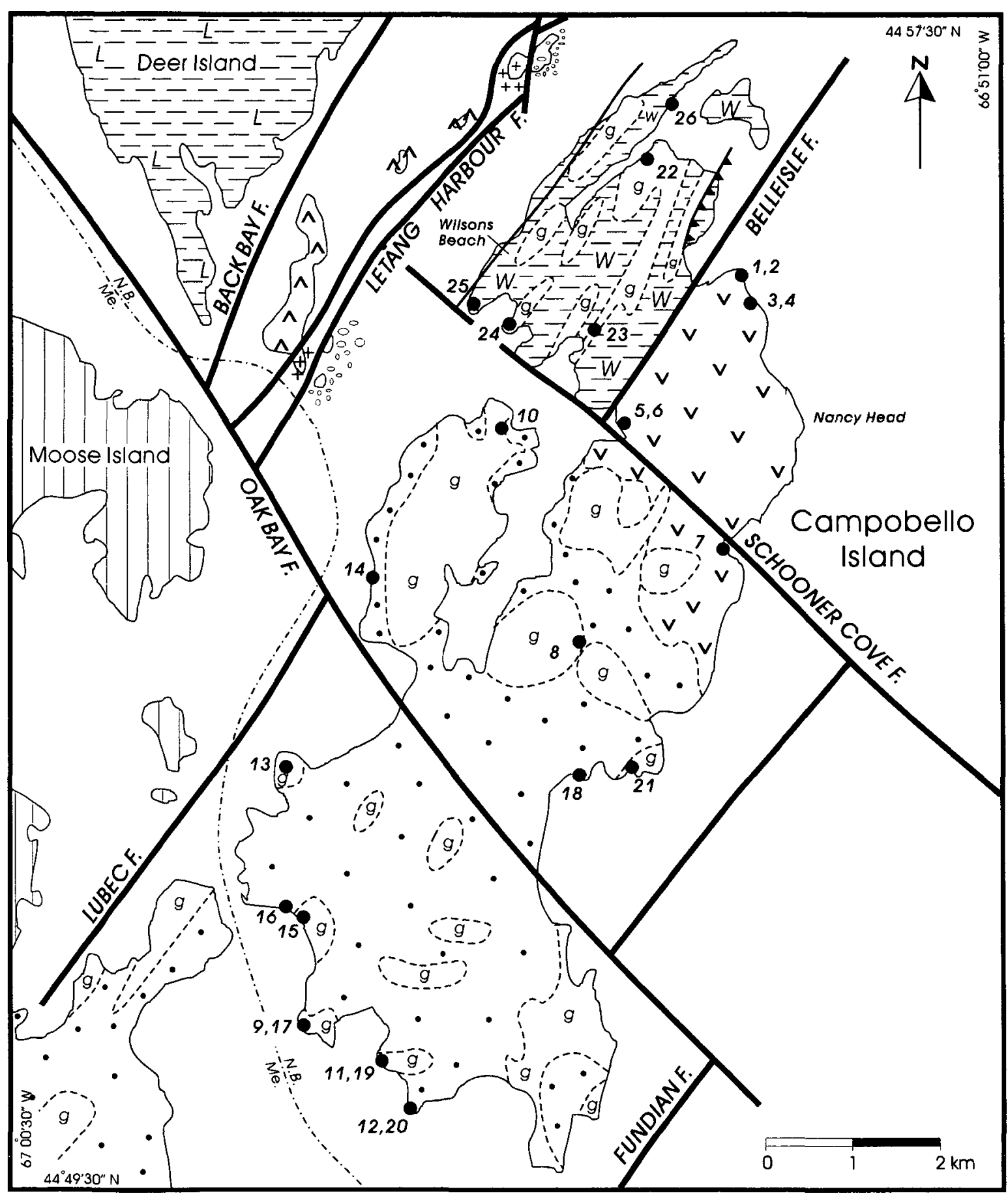

\section{LEGEND}

LATE DEVONIAN

$\begin{array}{llll}0 & 0 \\ 0 & 0 & 0\end{array}$ Perry Fm.

EARLY DEVONIAN

\begin{tabular}{|l|l|l}
\hline & & Eastport Fm.
\end{tabular}

\section{LATE SILURIAN}

- - - L Letete Fm.(L) and _- Wilsons Beach Fm.(W)

\section{EARLY SILURIAN}

$\because \because \because$ Quoddy Fm.

$\mathbf{v} \mathbf{v} \mathbf{v}$ Nancy Head Fm.

\section{SILURIAN}

9 Gabbro and diabase

LATE ORDOVICIAN TO EARLY SILURIAN

$\hat{\wedge \wedge \wedge}$ Simpsons Island Fm.

\section{NEOPROTEROZOIC}

$+{ }_{++}^{+}$Blacks Harbour granltoids

\section{SYMBOLS}

- Major fault

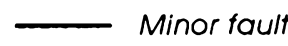

A. Minor thrust fault

-18 Geochemistry sample
location

-..... International border

Fig. 3. Geology of Campobello Island and geochemistry sample sites. Maine geology after Gates (1975). 

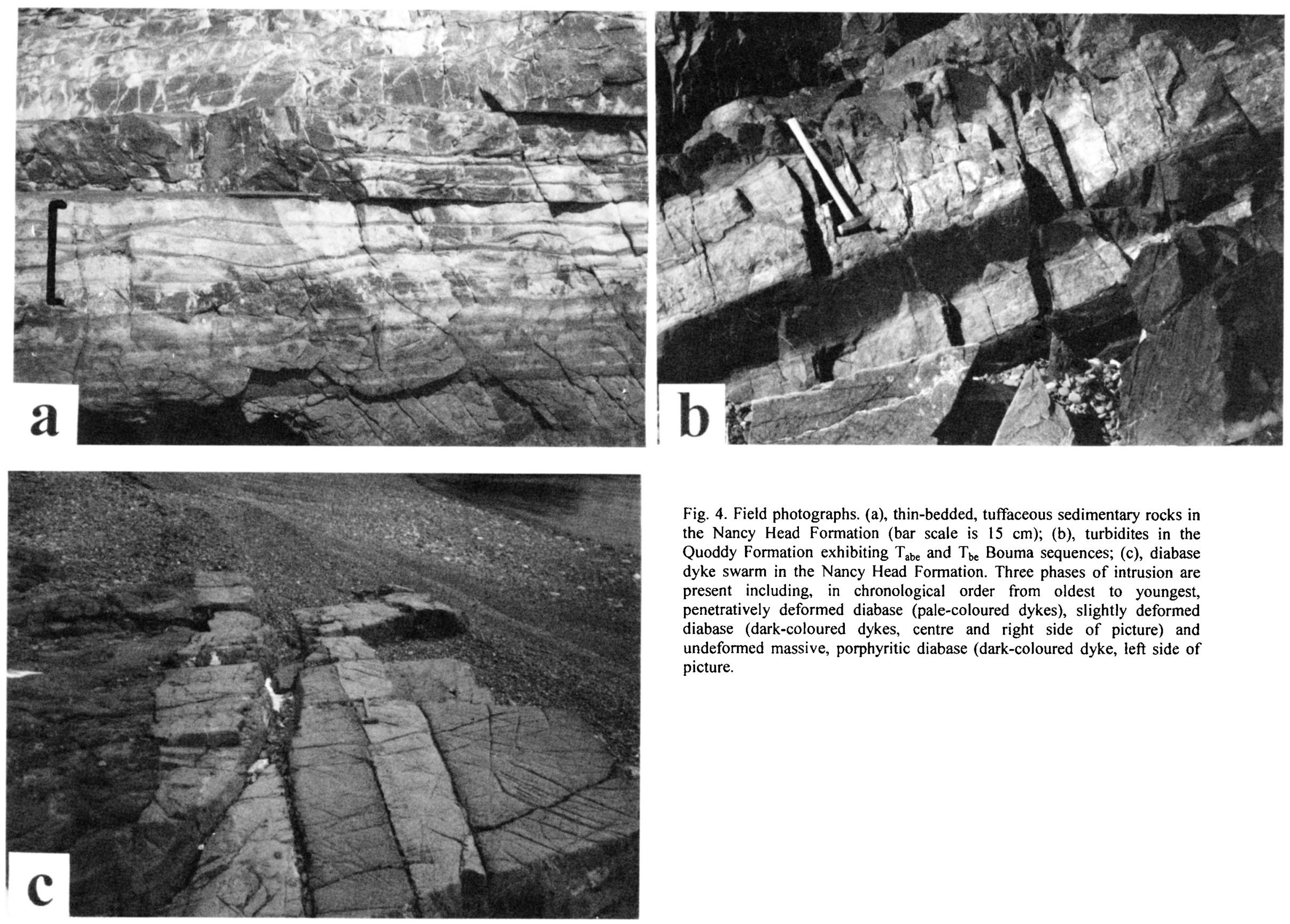

Fig. 4. Field photographs. (a), thin-bedded, tuffaceous sedimentary rocks in the Nancy Head Formation (bar scale is $15 \mathrm{~cm}$ ); (b), turbidites in the Quoddy Formation exhibiting $T_{\text {abe }}$ and $T_{b e}$ Bouma sequences; (c), diabase dyke swarm in the Nancy Head Formation. Three phases of intrusion are present including, in chronological order from oldest to youngest, penetratively deformed diabase (pale-coloured dykes), slightly deformed diabase (dark-coloured dykes, centre and right side of picture) and undeformed massive, porphyritic diabase (dark-coloured dyke, left side of picture. 
dipping beds to nearly vertical in a few localities. Away from the zones of intense dyking along the eastern shore, gently dipping beds define broad, open subhorizontal, northeast- or southwest-trending folds.

\section{Quoddy Formation}

The southern part of Campobello Island is underlain by the Quoddy Formation that contains Llandovery $\mathrm{C}_{3}-\mathrm{C}_{5}$ fossil assemblages in Maine (Berry and Boucot 1970). The formation was introduced by Bastin and Williams (1914) and has been described in detail in numerous publications by $\mathrm{O}$. Gates (e.g., Gates 1977). On Campobello Island it consists of locally pyritiferous, black to grey siltstone, lithic sandstone, shale and argillite intercalated with thick (up to several tens of metres) units that contain vesicular flows, agglomerate and/or well-developed hyaloclastite sequences. Many of the sedimentary beds exhibit features indicative of relatively proximal turbidites with $T_{b e}, T_{a b e}$ and $T_{c e}$ Bouma sequences most common (Fig. 4b). These features and the presence of thick to very thick $T_{a}$ divisions and pelitic intervals of variable thickness are consistent with deposition in a pro-delta slope environment. The fine-grained and some of the coarse-grained sedimentary rocks in this succession are affected by a single, weakly to well-developed cleavage, whereas most of the more massive mafic volcanic rocks appear unaffected by the deformation. The cleavage is axial planar to broad, gently southwest-plunging open folds with kilometre-scale wavelengths. These folds persist well into Maine (Gates 1977). In Maine, according to Gates $(1969,1984)$, the Quoddy Formation is restricted to the tract between the Lubec and Fundian faults and does not occur elsewhere in the region.

\section{Wilsons Beach Formation}

The Wilsons Beach Formation constitutes the northwestern part of the island and is bounded by the Belleisle and Schooner Cove faults to the southeast and southwest respectively. Presumably, it is bounded to the northeast by the Letang Harbour Fault and is overlain unconformably by the Perry Formation in the waters northeast of the island. Most units in the formation are well exposed along shore sections in the vicinity of the village of Wilsons Beach (Fig. 3). Minor(?) northeast-trending faults traverse the formation forming two, narrow, faulted units on either side of its main outcrop area. The westernmost fault is marked by a vertical shear zone, whereas that on the eastern side is a low-angle, west-directed thrust fault.

The main outcrop area constitutes a steeply dipping, northwest-facing section about $850 \mathrm{~m}$ thick. Although hampered by voluminous mafic intrusions and deformation, McLeod (1979) subdivided this section into two general volcanic-sedimentary units, of approximately equal thickness, separated by a mappable, mainly fine-grained clastic sedimentary unit. The lower part of the basal volcanicsedimentary unit consists of dark to light grey, mediumbedded siltstone with intercalated, thinly bedded fine- to medium-grained siliceous, tuffaceous sandstone. Coarsergrained lithologies predominate towards the top of the unit with minor proportions of mafic agglomerate, felsic lithic lapilli tuff, crystal tuff and feldspathic sandstone. The coarsergrained lithologies are commonly parallel laminated and locally cross-laminated or normally graded. The overlying fine-grained clastic unit consists predominantly of light to dark grey, finely laminated and massive siltstone and shale with minor intercalated coarser-grained tuffaceous beds. The upper volcanic-sedimentary unit is very similar to the upper part of the basal unit, but contains more abundant siliceous tuffaceous rocks.

The faulted unit to the northwest of the main outcrop area of the formation consists of steeply dipping, white-weathering, light grey, felsic, lithic lapilli tuff and agglomerate, and minor grey siltstone. The faulted unit to the east consists of shallowly dipping, massive, and vesicular flows of intermediate composition and thick beds of massive, dark grey siltstone. In places, large (up to $1 \mathrm{~m}$ ) flame structures are present where the flows were deposited on the unconsolidated siltstone units.

Tight and gently plunging, megascopic, first-phase folds, with a well-developed, north- to northeast-trending axial planar cleavage, define the overall outcrop pattern of the steeply dipping and northwest-facing units in the main outcrop of the formation. Minor first-phase folds plunge shallowly, vary in azimuth from $10^{\circ}$ to $45^{\circ}$ and exhibit a sense of vergence to the northwest and west. Polyphase deformation has resulted in the crenulation of the first phase cleavage and development of a weak second fabric locally, and later formation of conjugate kink bands in favourable lithologies.

\section{Stratigraphic relationships}

Before U-Pb dating studies (Doig et al. 1990; McLeod et al. 1994) established Lower Silurian ages for the northeastern part of the Kingston belt, the age of the felsic volcanic sequences and (in particular) the diabase dykes was contentious. Most workers in the belt, including Campobello Island, correlated the felsic volcanic rocks with the Neoproterozoic Coldbrook Group exposed in the Saint John area (McCutcheon and Ruitenberg 1987; Eby and Currie 1993; and in references in Barr et al. 1999) although a Silurian age was not ruled out by some (e.g., Helmstaedt 1968). The diabase dykes, however, have been ...assigned to the Neoproterozoic, or Silurian to Devonian, in whole or part. Accordingly, McLeod (1979) and McLeod and Rast (1988) assumed a Neoproterozoic age for the felsic sequence (and most of the intruding dykes) on Campobello Island and inferred an unconformity at the base of the fossiliferous Quoddy Formation to explain the age differences, outcrop distribution, lack of major faults in the vicinity of the contact, and apparent structural and metamorphic contrasts between the Quoddy and Nancy Head formations. Re-examination of the coastal section in the vicinity of the proposed unconformity and new exposures inland near the eastern shore of Campobello Island indicates a gradual transition between the Nancy Head and Quoddy formations. Although numerous diabase dykes hamper examination of the unconformity in coastal exposures, the onset of Quoddy Formation-like deposition begins stratigraphically above a thick $(30 \mathrm{~m})$ tuffaceous exhalative unit. This unit is thin- to mediumbedded and consists of alternating fine- to coarse-grained 
layers of nearly massive pyrite and pyrrhotite in a mafic tuffaceous matrix. Overlying this unit, several tens of metres of thin- to medium-bedded turbidites are interbedded with minor amounts of felsic tuffaceous sedimentary rocks reminiscent of Nancy Head Formation lithologies. Some exposures approximately at this stratigraphic interval along strike inland consist of felsic lithic lapilli tuff and breccia identical to those in the Nancy Head Formation and contain lapilli- to block-size turbidite and exhalite fragments. Stratigraphically above this interval, intercalated, welldeveloped turbidite and mafic volcanic sequences typical of the Quoddy Formation begin. The base of the exhalite unit is a logical horizon at which to place the base of the Quoddy Formation and, although the Nancy Head and Quoddy formations exhibit significant contrasts in composition, they constitute a virtually continuous stratigraphic succession. The orientation of megascopic folds on the southern part of Campobello Island indicates that the Nancy Head Formation plunges beneath the Quoddy Formation to the southwest (McLeod and Rast 1988).

\section{MAFIC INTRUSIONS}

\section{Mode of occurrence}

Abundant mafic intrusions are present in the Nancy Head, Quoddy, and Wilsons Beach formations on Campobello Island. In the following discussion, these intrusions are grouped according to formation and mode of occurrence, and abbreviated as follows: Nancy Head Formation diabase dykes = NHFD, Quoddy Formation gabbro bodies $=$ QFG, Quoddy Formation diabase and gabbro dykes $=$ QFD, and Wilsons Beach Formation gabbro intrusions $=$ WBFI. Although similar in many respects, especially those in the Nancy Head and Quoddy formations, details of their mode of occurrence and structural and metamorphic histories reveal important contrasts.

Single or swarms of northeast-trending and steeply dipping diabase dykes, which constitute over fifty percent of most sections, intrude the Nancy Head and Quoddy formations. Dyke thicknesses and lengths vary, but most are a few metres wide and can be traced over tens of metres. Two or three generations of dyke injection are exposed at many localities as indicated by well-developed chilled margins and crosscutting relationships (Fig. 4c). Pervasively to moderately deformed dykes occur only in the Nancy Head Formation and are always the oldest. In general, later dykes are equigranular, non-porphyritic to slightly plagioclase porphyritic, massive, and fine-grained. They are commonly intruded by aphanitic diabase with plagioclase porphyritic interiors. In addition to the diabase dykes, small (up to $1 \mathrm{~km}$ diameter) oblate, equigranular to ophitic, gabbroic plugs intrude the Quoddy Formation. Gates (1977) interpreted these as thick (up to 250 m) sills and sill-like tabular plutons in Maine. On Campobello Island, these also may be sequentially emplaced in that they appear to have intruded before and after the main period of dyke injection as indicated by the presence or absence of crosscutting dykes. However, the apparent lack of dykes in some of the gabbroic plugs could be a function of exposure in some areas.

Mafic intrusions in the Wilsons Beach Formation consist mostly of equigranular and subophitic gabbro, and typically occur as small bodies (less than one kilometre in length) elongate parallel to the north- to northeast-trending structural grain. Most of the intrusions are undeformed, but a few exhibit penetrative shearing (poorly developed cataclastic fabric) parallel to the regional fabric. Diabase dykes similar to those in the other formations are rare and, where present, do not occur in swarms.

\section{Petrography, mineralogy and metamorphism}

A representative suite of samples from mafic intrusions on Campobello Island was collected for scanning electron microprobe (SEM) analyses to quantify our petrographic analysis of amphibole, pyroxene, and plagioclase (Table 1). Ilmenite, variably altered to leucoxene, is the sole oxide phase in all samples (SEM data not shown). Sample locations are the same as those for lithogeochemical samples discussed below. Analyses were obtained by standard wavelength techniques using a JEOL-733 electron microprobe at the University of New Brunswick (Douglas Hall, analyst).

In the dykes of the Nancy Head Formation the original mineralogy is not preserved and, in most samples, pale- to medium-green actinolite with distinct blue-green hornblende rims (after pyroxene?) is ubiquitous. Commonly, nearly all the amphibole is blue green and the accompanying plagioclase compositions range from oligoclase to andesine. This lower amphibolite facies metamorphism overprints, in many samples, a pre-existing epidote-hornfels or greenschist assemblage containing epidote + variably sericitised plagioclase + actinolite \pm biotite. Blue-green amphibole is particularly well developed in the schistose dykes in which the effects of any early metamorphism have been obliterated; plagioclase grains are generally recrystallized and clear or have clear rims with abundant new-growth hornblende \pm quartz in the matrix. In these rocks, it is likely that the amphibolite-facies assemblage has partly pseudomorphed minerals developed in response to earlier deformation and metamorphism (lower grade?). Rarely, the amphibolites are retrogressed as indicated by scattered epidote overprinting all minerals and by the presence of chlorite. Late epidote veining and carbonate alteration is ubiquitous.

The intrusions in the Quoddy Formation exhibit a similar metamorphic history, but amphibolite facies assemblages do not occur everywhere and are not well developed where present. All gradations exist between samples with relict primary clinopyroxene (augite), partially pseudomorphed by actinolite, and accompanied by the remainder of the lower grade assemblages described above, to assemblages with actinolite pseudomorphs exhibiting well-developed bluegreen hornblende rims with or without relict pyroxene. Plagioclase compositions are normally albite in the gabbro bodies and range from albite to more calcic varieties in the dykes. Lower amphibolite facies mineralogy does not appear to be restricted to any particular generation of intrusions, but 
Table 1: SEM analyses of amphibole, plagioclase and pyroxene.

\begin{tabular}{|c|c|c|c|c|c|c|c|c|c|c|c|c|c|}
\hline $\begin{array}{l}\text { Sample } \\
\text { Wt. \% }\end{array}$ & $\mathrm{SiO}_{2}$ & $\mathrm{TiO}_{2}$ & $\mathrm{Al}_{2} \mathrm{O}_{3}$ & $\mathrm{FeO}^{\mathrm{T}}$ & $\mathrm{MnO}$ & $\mathrm{MgO}$ & $\mathrm{CaO}$ & $\mathrm{Na}_{2} \mathrm{O}$ & $\mathrm{K}_{2} \mathrm{O}$ & $\mathrm{Cr}_{2} \mathrm{O}_{3}$ & TOTAL & $\#$ & AREA \\
\hline $\begin{array}{l}\text { CM110a } \\
\text { (NHFD) }\end{array}$ & $\begin{array}{l}42.27 \\
51.14 \\
60.44\end{array}$ & $\begin{array}{l}0.40 \\
0.25 \\
0.07\end{array}$ & $\begin{array}{c}12.08 \\
4.00 \\
24.99\end{array}$ & $\begin{array}{c}23.5 \\
18.29 \\
0.46\end{array}$ & $\begin{array}{l}0.28 \\
0.34 \\
0.00\end{array}$ & $\begin{array}{c}6.97 \\
12.30 \\
0.02\end{array}$ & $\begin{array}{c}11.52 \\
12.10 \\
6.53\end{array}$ & $\begin{array}{l}1.51 \\
0.54 \\
7.82\end{array}$ & $\begin{array}{l}0.69 \\
0.10 \\
0.07\end{array}$ & $\begin{array}{l}0.03 \\
0.09 \\
0.02\end{array}$ & $\begin{array}{c}99.25 \\
99.15 \\
100.42\end{array}$ & $\begin{array}{l}4 \\
4 \\
2\end{array}$ & $\begin{array}{l}\text { am rim } \\
\text { am core } \\
\text { plag }\end{array}$ \\
\hline $\begin{array}{l}\text { CM73cl } \\
\text { (NHFD) }\end{array}$ & $\begin{array}{c}42.8 \\
51.11 \\
64.39\end{array}$ & $\begin{array}{l}0.31 \\
0.42 \\
0.03\end{array}$ & $\begin{array}{c}10.57 \\
2.89 \\
21.9\end{array}$ & $\begin{array}{c}22.85 \\
18.16 \\
0.31\end{array}$ & $\begin{array}{l}0.30 \\
0.32 \\
0.01\end{array}$ & $\begin{array}{c}7.42 \\
12.36 \\
0.01\end{array}$ & $\begin{array}{c}11.96 \\
12.18 \\
3.00\end{array}$ & $\begin{array}{c}1.36 \\
0.44 \\
10.37\end{array}$ & $\begin{array}{l}0.44 \\
0.06 \\
0.07\end{array}$ & $\begin{array}{l}0.03 \\
0.02 \\
0.03\end{array}$ & $\begin{array}{c}98.04 \\
97.96 \\
100.12\end{array}$ & $\begin{array}{l}4 \\
4 \\
2\end{array}$ & $\begin{array}{l}\text { am rim } \\
\text { am core } \\
\text { plag }\end{array}$ \\
\hline $\begin{array}{l}\text { CM47cl } \\
\text { (NHFD) }\end{array}$ & $\begin{array}{l}45.41 \\
50.44 \\
59.56\end{array}$ & $\begin{array}{l}0.34 \\
0.43 \\
0.00\end{array}$ & $\begin{array}{c}11.16 \\
6.12 \\
25.34\end{array}$ & $\begin{array}{c}17.40 \\
14.99 \\
0.24\end{array}$ & $\begin{array}{l}0.26 \\
0.39 \\
0.00\end{array}$ & $\begin{array}{c}10.52 \\
13.66 \\
0.00\end{array}$ & $\begin{array}{c}11.96 \\
12.27 \\
6.99\end{array}$ & $\begin{array}{l}1.12 \\
0.61 \\
7.88\end{array}$ & $\begin{array}{l}0.31 \\
0.11 \\
0.08\end{array}$ & $\begin{array}{l}0.03 \\
0.04 \\
0.00\end{array}$ & $\begin{array}{c}98.51 \\
99.06 \\
100.09\end{array}$ & $\begin{array}{l}4 \\
4 \\
2\end{array}$ & $\begin{array}{l}\text { am rim } \\
\text { am core } \\
\text { plag }\end{array}$ \\
\hline $\begin{array}{l}\text { CM47c2 } \\
\text { (NHFD) }\end{array}$ & $\begin{array}{c}41.6 \\
47.69 \\
42.55 \\
60.00\end{array}$ & $\begin{array}{l}0.37 \\
0.56 \\
0.40 \\
0.03\end{array}$ & $\begin{array}{c}13.82 \\
7.59 \\
14.37 \\
25.77\end{array}$ & $\begin{array}{c}20.58 \\
17.15 \\
19.67 \\
0.42\end{array}$ & $\begin{array}{l}0.24 \\
0.27 \\
0.30 \\
0.02\end{array}$ & $\begin{array}{c}7.76 \\
11.41 \\
7.52 \\
0.03\end{array}$ & $\begin{array}{c}11.87 \\
12.11 \\
11.71 \\
7.24\end{array}$ & $\begin{array}{l}1.31 \\
0.82 \\
1.62 \\
7.65\end{array}$ & $\begin{array}{l}0.55 \\
0.19 \\
0.56 \\
0.05\end{array}$ & $\begin{array}{l}0.03 \\
0.06 \\
0.03 \\
0.02\end{array}$ & $\begin{array}{c}98.13 \\
97.85 \\
98.73 \\
101.23\end{array}$ & $\begin{array}{l}4 \\
4 \\
1 \\
2\end{array}$ & $\begin{array}{l}\text { am rim } \\
\text { am core } \\
m x \text { blade } \\
\text { plag }\end{array}$ \\
\hline $\begin{array}{l}\text { CM124d } \\
\text { (GFG) }\end{array}$ & $\begin{array}{l}45.87 \\
52.20 \\
52.68 \\
50.46 \\
51.04 \\
66.47\end{array}$ & $\begin{array}{l}0.14 \\
0.13 \\
0.37 \\
0.92 \\
0.89 \\
0.01\end{array}$ & $\begin{array}{c}11.69 \\
4.90 \\
3.17 \\
2.89 \\
3.04 \\
20.89\end{array}$ & $\begin{array}{c}18.22 \\
15.69 \\
13.22 \\
7.75 \\
7.45 \\
0.07\end{array}$ & $\begin{array}{l}0.35 \\
1.53 \\
0.27 \\
0.17 \\
0.21 \\
0.02\end{array}$ & $\begin{array}{c}9.31 \\
12.97 \\
14.43 \\
15.5 \\
15.83 \\
0.00\end{array}$ & $\begin{array}{c}12.51 \\
12.61 \\
13.21 \\
21.54 \\
21.53 \\
1.62\end{array}$ & $\begin{array}{c}0.96 \\
0.48 \\
0.26 \\
0.34 \\
0.35 \\
11.01\end{array}$ & $\begin{array}{c}0.29 \\
0.13 \\
0.07 \\
0.01 \\
0.0 \\
0.11\end{array}$ & $\begin{array}{l}0.02 \\
0.02 \\
0.09 \\
0.14 \\
0.16 \\
0.00\end{array}$ & $\begin{array}{c}99.36 \\
100.66 \\
97.77 \\
99.72 \\
100.5 \\
100.2\end{array}$ & $\begin{array}{l}1 \\
1 \\
3 \\
3 \\
3 \\
2\end{array}$ & $\begin{array}{l}\text { am rim } \\
\text { am core } \\
\text { pn mantle } \\
\text { pn rim } \\
\text { pn rim } \\
\text { plag }\end{array}$ \\
\hline $\begin{array}{l}\text { CM140a } \\
\text { (QFG) }\end{array}$ & $\begin{array}{l}44.17 \\
50.41 \\
66.13\end{array}$ & $\begin{array}{l}0.05 \\
0.10 \\
0.01\end{array}$ & $\begin{array}{c}11.73 \\
3.42 \\
20.32\end{array}$ & $\begin{array}{c}25.03 \\
24.26 \\
0.11\end{array}$ & $\begin{array}{l}0.33 \\
0.48 \\
0.00\end{array}$ & $\begin{array}{l}4.71 \\
7.76 \\
0.00\end{array}$ & $\begin{array}{c}11.79 \\
11.97 \\
1.29\end{array}$ & $\begin{array}{c}0.99 \\
0.33 \\
11.15\end{array}$ & $\begin{array}{l}0.48 \\
0.13 \\
0.07\end{array}$ & $\begin{array}{l}0.04 \\
0.03 \\
0.02\end{array}$ & $\begin{array}{c}99.32 \\
98.89 \\
99.1\end{array}$ & $\begin{array}{l}4 \\
4 \\
2\end{array}$ & $\begin{array}{l}\text { am rim } \\
\text { am core } \\
\text { plag }\end{array}$ \\
\hline $\begin{array}{l}\text { CM122b } \\
\text { (QFD) }\end{array}$ & $\begin{array}{l}41.81 \\
51.65 \\
67.16\end{array}$ & $\begin{array}{l}0.17 \\
0.21 \\
0.02\end{array}$ & $\begin{array}{c}16.06 \\
3.66 \\
20.48\end{array}$ & $\begin{array}{c}20.76 \\
15.73 \\
0.14\end{array}$ & $\begin{array}{l}0.21 \\
0.24 \\
0.02\end{array}$ & $\begin{array}{c}6.2 \\
13.26 \\
0.02\end{array}$ & $\begin{array}{c}12.07 \\
13.35 \\
1.16\end{array}$ & $\begin{array}{c}1.24 \\
0.31 \\
11.07\end{array}$ & $\begin{array}{l}0.58 \\
0.09 \\
0.07\end{array}$ & $\begin{array}{l}0.05 \\
0.09 \\
0.02\end{array}$ & $\begin{array}{c}99.15 \\
98.59 \\
100.16\end{array}$ & $\begin{array}{l}4 \\
4 \\
2\end{array}$ & $\begin{array}{l}\text { am rim } \\
\text { am core } \\
\text { plag }\end{array}$ \\
\hline $\begin{array}{l}\text { CM144b } \\
\text { (QFD) }\end{array}$ & $\begin{array}{l}43.60 \\
50.65 \\
49.30 \\
47.10 \\
53.08\end{array}$ & $\begin{array}{l}0.32 \\
0.16 \\
0.16 \\
0.21 \\
0.08\end{array}$ & $\begin{array}{c}12.43 \\
5.46 \\
7.19 \\
8.99 \\
29.48\end{array}$ & $\begin{array}{c}18.65 \\
14.5 \\
15.88 \\
17.85 \\
0.64\end{array}$ & $\begin{array}{l}0.23 \\
0.28 \\
0.24 \\
0.29 \\
0.17\end{array}$ & $\begin{array}{c}9.61 \\
14.57 \\
13.87 \\
11.83 \\
0.11\end{array}$ & $\begin{array}{l}11.67 \\
11.65 \\
11.02 \\
11.07 \\
11.66\end{array}$ & $\begin{array}{l}1.73 \\
0.74 \\
0.97 \\
1.23 \\
4.69\end{array}$ & $\begin{array}{l}0.23 \\
0.10 \\
0.10 \\
0.14 \\
0.27\end{array}$ & $\begin{array}{l}0.04 \\
0.06 \\
0.02 \\
0.04 \\
0.03\end{array}$ & $\begin{array}{c}98.51 \\
98.17 \\
98.75 \\
98.75 \\
100.21\end{array}$ & $\begin{array}{l}2 \\
2 \\
2 \\
2 \\
2\end{array}$ & $\begin{array}{l}\text { am rim } \\
\text { am core } \\
\text { am dark } \\
\text { am light } \\
\text { plag }\end{array}$ \\
\hline $\begin{array}{l}\text { CM66cl } \\
\text { (WBFI) }\end{array}$ & $\begin{array}{l}49.37 \\
53.13 \\
53.55 \\
49.84 \\
47.93 \\
49.10 \\
44.46 \\
66.47\end{array}$ & $\begin{array}{l}0.05 \\
0.04 \\
0.11 \\
0.13 \\
0.05 \\
0.12 \\
0.04 \\
0.01\end{array}$ & $\begin{array}{c}4.53 \\
1.60 \\
2.38 \\
4.93 \\
5.72 \\
4.93 \\
9.86 \\
19.52\end{array}$ & $\begin{array}{c}22.16 \\
18.27 \\
16.96 \\
22.66 \\
22.63 \\
22.65 \\
24.77 \\
0.86\end{array}$ & $\begin{array}{l}0.24 \\
0.38 \\
0.27 \\
0.29 \\
0.25 \\
0.35 \\
0.23 \\
0.00\end{array}$ & $\begin{array}{c}9.66 \\
12.8 \\
13.24 \\
9.45 \\
8.80 \\
8.63 \\
6.55 \\
0.03\end{array}$ & $\begin{array}{c}12.11 \\
12.46 \\
12.6 \\
12.05 \\
11.81 \\
11.81 \\
11.78 \\
0.65\end{array}$ & $\begin{array}{c}0.61 \\
0.25 \\
0.28 \\
0.66 \\
0.72 \\
0.54 \\
1.07 \\
11.41\end{array}$ & $\begin{array}{l}0.30 \\
0.06 \\
0.08 \\
0.28 \\
0.21 \\
0.32 \\
0.69 \\
0.09\end{array}$ & $\begin{array}{l}0.03 \\
0.04 \\
0.03 \\
0.06 \\
0.04 \\
0.04 \\
0.02 \\
0.01\end{array}$ & $\begin{array}{c}99.06 \\
99.03 \\
99.50 \\
100.35 \\
98.16 \\
98.49 \\
99.47 \\
99.05\end{array}$ & $\begin{array}{l}3 \\
3 \\
1 \\
1 \\
1 \\
1 \\
1 \\
2\end{array}$ & $\begin{array}{l}\text { am rim } \\
\text { am core } \\
\text { am dark } \\
\text { am light } \\
\text { am blade } \\
\text { am blade } \\
\text { blade edge } \\
\text { plag }\end{array}$ \\
\hline $\begin{array}{l}\text { CM22cl } \\
\text { (WBFI) }\end{array}$ & $\begin{array}{l}47.96 \\
52.16 \\
52.76 \\
50.58 \\
65.22\end{array}$ & $\begin{array}{l}0.10 \\
0.19 \\
0.42 \\
0.67 \\
0.00\end{array}$ & $\begin{array}{c}7.91 \\
3.26 \\
1.77 \\
2.68 \\
21.93\end{array}$ & $\begin{array}{c}19.58 \\
16.13 \\
16.34 \\
22.41 \\
0.38\end{array}$ & $\begin{array}{l}0.34 \\
0.27 \\
0.31 \\
0.64 \\
0.02\end{array}$ & $\begin{array}{c}9.93 \\
13.33 \\
13.68 \\
10.83 \\
0.01\end{array}$ & $\begin{array}{c}11.86 \\
12.46 \\
12.49 \\
10.26 \\
2.94\end{array}$ & $\begin{array}{c}0.76 \\
0.32 \\
0.15 \\
0.30 \\
10.00\end{array}$ & $\begin{array}{l}0.21 \\
0.06 \\
0.02 \\
0.47 \\
0.12\end{array}$ & $\begin{array}{l}0.04 \\
0.03 \\
0.04 \\
0.03 \\
0.02\end{array}$ & $\begin{array}{c}98.69 \\
98.21 \\
97.98 \\
98.87 \\
100.64\end{array}$ & $\begin{array}{l}3 \\
3 \\
1 \\
1 \\
2\end{array}$ & $\begin{array}{l}\text { am rim } \\
\text { am core } \\
\text { am dark } \\
\text { am light } \\
\text { plag }\end{array}$ \\
\hline
\end{tabular}

Notes: \# column = number of crystals analyzed in sample; abbreviations and additional explanation: am = amphibole, pn = pyroxene, plag = plagioclase, $\mathrm{mx}=$ matrix, rim, core and/or mantle are paired analyses from the same crystals, blade $=$ new-growth crystals in matrix, dark and light are paired analyses of variegated crystals with no distinct rims. See text for additional abbreviations. The probe was operated with a $15 \mathrm{kV}$ accelerating voltage and a probe current of $10 \mathrm{nA}$. Maximun peak counting times of 40 seconds were employed. Detection limits were 0.02 wt. \% for all elements except $\mathrm{MnO}$ and $\mathrm{FeO}$, which were 0.04 wt.\%. 
less metamorphosed intrusions with relict pyroxene grains are mainly gabbroic plugs or a few of the coarser-grained dykes.

In general, the intrusions in the Wilsons Beach Formation differ from those described above in that blue-green hornblende rimming actinolite was observed only in one sample. Plagioclase is albitic in most samples and relict clinopyroxene is normally preserved. These features, and the ubiquitous presence of epidote + chlorite, indicate lower metamorphic grades overall in the greenschist or epidotehornfels facies.

\section{Lithogeochemistry}

\section{Sample collection and analytical techniques}

Twenty-six analyses of mafic intrusive rocks from the three formations on Campobello Island are shown in Table 2. Seven schistose and massive, non-porphyritic diabase dykes were sampled from the Nancy Head Formation and fourteen samples were collected from the Quoddy Formation, the latter being all undeformed and representative of gabbro plugs and porphyritic to non-porphyritic diabase dykes. The remaining five samples were massive to slightly sheared gabbro from the Wilsons Beach Formation.

Samples were milled at the Minerals Engineering Centre, Technical University of Nova Scotia, Halifax, Nova Scotia, and analyzed in 1990 at St. Mary's University, Halifax, Nova Scotia following the procedures outlined in Fyffe and Pickerill (1993). The major elements, minor elements, and $\mathrm{Ba}, \mathrm{Rb}, \mathrm{Sr}$, $\mathrm{Y}, \mathrm{Zr}, \mathrm{Nb}, \mathrm{Ga}, \mathrm{Zn}, \mathrm{Cu}, \mathrm{Ni}, \mathrm{V}$ and $\mathrm{Cr}$, were determined by $\mathrm{X}-$ ray fluorescence spectrometry. Loss on ignition was determined by standard dry chemical techniques and the remainder of the trace elements were analyzed by instrumental neutron activation. Low $\mathrm{Nb}$ concentrations, which were reported as less than detection limit ( $<5 \mathrm{ppm})$, are, for plotting purposes, arbitrarily assigned a value of $2.5 \mathrm{ppm}$.

\section{Chemical Characteristics}

As described in the previous sections, the mafic intrusions have been subjected to a broad spectrum of metamorphic and/or alteration affects. Accordingly, varying degrees of mobility for some major elements are apparent as is indicated on the alkali diagram, where many samples plot outside the igneous spectrum in the spilitic field (Fig. 5a). Binary plots were used to obtain some indication of mobility in other elements commonly used in classification and discrimination diagrams. Various combinations of incompatible and normally immobile elements (e.g., $\mathrm{Zr}$ ) were plotted against a range of major and minor elements, and other more or less incompatible trace elements. In general, if pairs of elements exhibit reasonable linear correlation irrespective of metamorphism and alteration, then the likelihood of their mobility is minimized, and they are most reliable in characterizing the intrusions. Plots demonstrate that this is the case for elements such as $\mathrm{Si}, \mathrm{Mg}, \mathrm{P}, \mathrm{Th}, \mathrm{Ta}, \mathrm{Ce}, \mathrm{Hf}, \mathrm{Zr}$ and $\mathrm{Y}$ (Fig. 5b-5i). Others, such as $\mathrm{Fe}$ and $\mathrm{Ti}$, show significant scatter like the alkalis, and may be relatively mobile (Fig. $5 j-$ 51). In the following discussion, the diagrams using the more mobile elements and those with less than detection limit concentrations of $\mathrm{Nb}$ must be viewed with caution.
Binary plots of $\mathrm{SiO}_{2}$ and $\mathrm{FeO}^{\mathrm{T}}$ vs. $\mathrm{FeO}^{\mathrm{T}} / \mathrm{MgO}$, and $\mathrm{Zr} / \mathrm{TiO}_{2}$ vs. $\mathrm{SiO}_{2}$ and $\mathrm{Nb} / \mathrm{Y}$ indicate that the intrusions are mostly tholeiitic subalkaline basalt, with some basaltic andesite (Fig. 6a-6d). On three commonly used ternary plots using high-field-strength and, normally, immobile elements, the tectonic setting of the intrusions is somewhat ambiguous. Samples on two of the diagrams, which incorporate $\mathrm{Zr}$ and $\mathrm{Y}$ with $\mathrm{Ti}$ or $\mathrm{Nb}$, plot in either the within-plate basalt to calcalkalic basalt or volcanic-arc basalt fields (Fig. 7a and b). On the third diagram, however, a volcanic-arc basalt character is clearly indicated (Fig. 7c). It is notable that only elements considered immobile in this study are used on the latter diagram. Averages of data from diabase dykes along strike on mainland New Brunswick (Fig. 7a and 7b) and Maine (Fig. 7c) are also plotted on these diagrams for comparison.

Simplified variation diagrams devised by Pearce (1996) using commonly immobile elements arranged in order of their relative incompatibility, increasing from left to right and normalized to N-MORB, were also utilized to characterize the tectonic setting of the mafic intrusions on Campobello Island (Fig. 8a, 8b, 8c and 8d). Ta has been substituted for $\mathrm{Nb}$ as recommended by Pearce (1996) for instances where $\mathrm{Nb}$ concentrations reported are not satisfactory. Representative samples from each of the main groupings of intrusions are plotted on these diagrams to demonstrate maximum variation within each group. In the least incompatible elements ( $\mathrm{Ce}$ to Y), most samples from all four of the main groups define patterns generally similar to those found in within plate and attenuated continental lithospheric settings, but are elevated in absolute concentrations. All groups also exhibit pronounced negative $\mathrm{Ta}$ anomalies (and low $\mathrm{Nb}$ values) found in arc-type basalts and are somewhat elevated in Th. Most elements in QFG show a fairly wide range of absolute concentrations that may reflect differentiation processes as discussed below. For comparison, similar plots are presented for dykes along strike on mainland New Brunswick and Maine using available data (Fig. 7e) and these show similar profiles to those on Campobello Island.

On rare-earth-element (REE) plots (Fig. 9a, 9b, 9c and 9d), most samples from Campobello Island define fairly consistent, straight profiles with moderate light-rare-earth element (LREE) and middle-rare-earth element (MREE) enrichment. Sample number 10 from the QFG and number 24 from the WBFI are exceptions that exhibit LREE depleted and enriched profiles respectively. Disregarding these, the remainder yield low $\mathrm{La} / \mathrm{Lu}_{\mathrm{N}}$ ratios $\left(\mathrm{La} / \mathrm{Lu} \mathrm{N}_{\mathrm{N}}\right.$ ratios: NHFD $=$ $1.9-2.9, \mathrm{QFD}=2.2-2.5, \mathrm{QFG}=1.8-2.9, \mathrm{WBFI}=1.5-2.1)$. There is some variability in total REE (REE ${ }^{\top}$ ) within and between groups and absolute concentrations are high for tholeiitic rocks $\left(\mathrm{REE}^{\mathrm{T}}: \mathrm{NHFD}=346-655\right.$, QFD $=281-430$, QFG $=203-590$, WBFI $=304-448$ ). In calculating $\operatorname{REE}^{\mathrm{T}}$ contents, concentrations of REE's not analyzed were estimated from the REE profiles. Overall, $\mathrm{REE}^{\mathrm{T}}$ for the NHFD are higher than those for the QFD, and values for the QFG nearly span the entire ranges of the other main groups. There are no apparent systematic variations within or between the main groupings of intrusions with respect to timing of emplacement (i.e., deformed vs. undeformed dykes in the NHFD) or with degree of metamorphism. REE plots are also 
Table 2: Chemical analyses of matic intrusions.

\begin{tabular}{|c|c|c|c|c|c|c|c|c|c|c|c|c|c|c|c|c|c|c|c|c|c|c|c|c|c|c|}
\hline & \multicolumn{7}{|c|}{ Nancy Head Formation (NHFD) } & \multicolumn{6}{|c|}{ Quoddy Formation (QFG) } & \multicolumn{8}{|c|}{ Quoddy Formation (QFD) } & \multicolumn{5}{|c|}{ Wilsons Beach Formation (WBFI) } \\
\hline & $\begin{array}{c}1 \\
45 \mathrm{cl}\end{array}$ & $\begin{array}{c}2 \\
45 \mathrm{c} 2 \\
\end{array}$ & $\begin{array}{c}3 \\
47 \mathrm{cl} \\
\end{array}$ & $\begin{array}{c}4 \\
47 c 2 \\
\end{array}$ & $\begin{array}{c}5 \\
73 \mathrm{cl} \\
\end{array}$ & $\begin{array}{c}6 \\
73 \mathrm{c} 3 \\
\end{array}$ & $\begin{array}{c}7 \\
110 a \\
\end{array}$ & $\begin{array}{c}8 \\
57 \mathrm{cl} \\
\end{array}$ & $\begin{array}{c}9 \\
124 \mathrm{~d} \\
\end{array}$ & $\begin{array}{c}10 \\
127 \mathrm{c} 2 \\
\end{array}$ & $\begin{array}{c}11 \\
140 \mathrm{a} \\
\end{array}$ & $\begin{array}{c}12 \\
141 \mathrm{c}\end{array}$ & $\begin{array}{c}13 \\
152 c 2 \\
\end{array}$ & $\begin{array}{c}14 \\
87 \mathrm{cl} \\
\end{array}$ & $\begin{array}{c}15 \\
122 \mathrm{~b}\end{array}$ & $\begin{array}{c}16 \\
123 \mathrm{c} \\
\end{array}$ & $\begin{array}{c}17 \\
124 \mathrm{a} \\
\end{array}$ & $\begin{array}{c}18 \\
138 \\
\end{array}$ & $\begin{array}{c}19 \\
140 \mathrm{~b}\end{array}$ & $\begin{array}{c}20 \\
141 \mathrm{~b} \\
\end{array}$ & $\begin{array}{c}21 \\
144 \mathrm{~b} \\
\end{array}$ & $\begin{array}{c}22 \\
20 \mathrm{cl} \\
\end{array}$ & $\begin{array}{c}23 \\
22 \mathrm{cl}\end{array}$ & $\begin{array}{c}24 \\
42 \mathrm{cl} \\
\end{array}$ & $\begin{array}{c}25 \\
66 \mathrm{cl} \\
\end{array}$ & $\begin{array}{c}26 \\
79 \mathrm{cl} \\
\end{array}$ \\
\hline $\mathrm{SiO}_{2}$ & 51.45 & 53.77 & 50.27 & 47.89 & 51.19 & 48.65 & 48.98 & 47.64 & 47.77 & 46.69 & 53.68 & 48.38 & 52.87 & 50.20 & 48.35 & 49.99 & 52.20 & 49.69 & 50.92 & 48.27 & 48.41 & 48.69 & 48.84 & 48.88 & 49.28 & 49.32 \\
\hline $\mathrm{TiO}_{2}$ & 2.65 & 1.95 & 1.85 & 2.71 & 3.05 & 2.74 & 2.39 & 2.68 & 1.56 & 1.89 & 2.35 & 2.48 & 2.53 & 2.99 & 2.13 & 1.80 & 0.93 & 2.79 & 2.14 & 1.99 & 1.82 & 2.30 & 2.33 & 1.29 & 2.86 & 1.72 \\
\hline $\mathrm{Al}_{2} \mathrm{O}_{3}$ & 13.99 & 14.67 & 15.72 & 13.73 & 12.94 & 13.77 & 13.95 & 14.52 & 14.36 & 16.58 & 13.71 & 15.79 & 13.73 & 13.74 & 14.54 & 15.72 & 20.30 & 14.02 & 14.00 & 14.64 & 15.12 & 14.25 & 14.22 & 17.34 & 14.11 & 14.42 \\
\hline $\mathrm{Fe}_{2} \mathrm{O}_{3}{ }^{\top}$ & 12.79 & 10.88 & 10.65 & 13.80 & 14.19 & 13.3 & 13.25 & 12.16 & 9.79 & 10.04 & 12.57 & 10.75 & 11.58 & 15.24 & 11.86 & 10.76 & 6.61 & 13.44 & 12.29 & 11.99 & 11.32 & 13.11 & 13.18 & 9.61 & 13.01 & 10.89 \\
\hline $\mathrm{MnO}$ & 0.21 & 0.26 & 0.23 & 0.25 & 0.23 & 0.23 & 0.21 & 0.19 & 0.2 & 0.17 & 0.24 & 0.18 & 0.21 & 0.24 & 0.18 & 0.18 & 0.13 & 0.23 & 0.19 & 0.20 & 0.21 & 0.21 & 0.21 & 0.16 & 0.20 & 0.19 \\
\hline $\mathrm{MgO}$ & 4.73 & 4.55 & 6.27 & 5.48 & 4.17 & 5.54 & 5.31 & 6.90 & 6.49 & 7.88 & 2.89 & 5.62 & 3.76 & 5.14 & 6.19 & 6.03 & 4.20 & 4.90 & 5.14 & 7.42 & 7.29 & 6.08 & 5.88 & 6.38 & 4.95 & 6.62 \\
\hline $\mathrm{CaO}$ & 5.98 & 6.80 & 8.76 & 10.38 & 7.98 & 8.92 & 9.45 & 9.40 & 10.35 & 9.73 & 7.41 & 9.52 & 7.51 & 5.92 & 10.04 & 9.29 & 7.28 & 8.61 & 7.96 & 10.51 & 9.51 & 8.45 & 8.50 & 7.84 & 7.40 & 9.53 \\
\hline $\mathrm{Na}_{2} \mathrm{O}$ & 4.17 & 4.06 & 3.49 & 2.43 & 4.28 & 3.60 & 3.21 & 2.86 & 3.82 & 2.48 & 4.52 & 3.99 & 3.66 & 3.54 & 3.08 & 2.40 & 4.31 & 3.83 & 3.76 & 2.38 & 3.23 & 3.48 & 3.24 & 3.87 & 4.13 & 2.07 \\
\hline $\mathrm{K}_{2} \mathrm{O}$ & 1.71 & 0.72 & 1.00 & 0.68 & 0.59 & 0.75 & 0.78 & 0.81 & 0.68 & 0.54 & 0.68 & 0.55 & 0.35 & 0.23 & 0.60 & 1.70 & 1.34 & 0.40 & 0.99 & 0.75 & 0.72 & 0.40 & 0.38 & 0.89 & 0.63 & 1.05 \\
\hline $\mathrm{P}_{2} \mathrm{O}_{3}$ & 0.44 & 0.45 & 0.29 & 0.52 & 0.45 & 0.42 & 0.28 & 0.36 & 0.28 & 0.17 & 0.64 & 0.38 & 0.67 & 0.34 & 0.26 & 0.27 & 0.10 & 0.42 & 0.36 & 0.21 & 0.21 & 0.25 & 0.25 & 0.49 & 0.32 & 0.19 \\
\hline $\begin{array}{l}\text { LOI } \\
\text { Total }\end{array}$ & $\frac{0.9}{99.02}$ & $\frac{0.9}{99.01}$ & $\frac{1.0}{99.53}$ & $\frac{0.7}{98.57}$ & $\frac{0.5}{99.57}$ & $\frac{0.9}{98.82}$ & $\frac{1.0}{98.81}$ & $\frac{1.0}{98.52}$ & $\frac{3.8}{99.10}$ & $\frac{2.9}{99.07}$ & $\frac{1.2}{99.89}$ & $\frac{1.5}{99.14}$ & $\frac{3.0}{99.87}$ & $\frac{2.6}{100.2}$ & $\frac{1.8}{99.03}$ & $\begin{array}{r}0.8 \\
98.94\end{array}$ & $\frac{2.2}{99.60}$ & $\frac{0.7}{99.03}$ & $\frac{1.3}{99.05}$ & $\frac{0.9}{99.26}$ & $\frac{1.3}{99.14}$ & $\frac{2.3}{99.52}$ & $\frac{2.3}{99.33}$ & $\frac{2.9}{99.65}$ & $\frac{2.7}{99.59}$ & $\frac{3.3}{99.30}$ \\
\hline $\mathrm{Ba}$ & 299 & 178 & 291 & 109 & 110 & 309 & 91 & 113 & 156 & 147 & 283 & 64 & 87 & 14 & 98 & 356 & 174 & 80 & 195 & 104 & 112 & 90 & 82 & 295 & 142 & 193 \\
\hline $\mathrm{Rb}$ & 62 & 18 & 29 & 19 & 14 & 21 & 27 & 25 & 28 & 34 & 15 & 18 & 12 & 11 & 20 & 41 & 53 & 21 & 30 & 22 & 27 & 19 & 14 & 23 & 18 & 53 \\
\hline Sr & 169 & 286 & 353 & 194 & 198 & 290 & 277 & 243 & 335 & 346 & 271 & 344 & 311 & 163 & 288 & 258 & 453 & 243 & 317 & 241 & 281 & 291 & 287 & 560 & 313 & 354 \\
\hline Y & 45 & 51 & 39 & 40 & 49 & 37 & 35 & 33 & 27 & 23 & 64 & 28 & 47 & 39 & 32 & 34 & 27 & 40 & 28 & 28 & 29 & 33 & 32 & 22 & 35 & 30 \\
\hline $\mathrm{Zr}$ & 246 & 348 & 226 & 188 & 278 & 198 & 160 & 165 & 114 & 88 & 347 & 145 & 257 & 194 & 154 & 176 & 184 & 212 & 162 & 136 & 137 & 151 & 150 & 192 & 161 & 151 \\
\hline $\mathrm{Nb}$ & 6 & 11 & 5 & 5 & 7 & 2.5 & 2.5 & 5 & 2.5 & 2.5 & 14 & 6 & 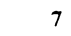 & 5 & 2.5 & 2.5 & 2.5 & 7 & 2.5 & 2.5 & 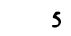 & 2.5 & 2.5 & 6 & 2.5 & 2.5 \\
\hline Th & 3.5 & 4.0 & 2.0 & 0.8 & 2.7 & 1.8 & 1.4 & 1.0 & 0.7 & 0.2 & 2.2 & 1.0 & 4.0 & 1.4 & 0.0 & 2.0 & 4.6 & 1.8 & 2.1 & 0.5 & 1.0 & 1.0 & 0.9 & 2.3 & 1.6 & 1.8 \\
\hline Ga & 19 & 22 & 20 & 19 & 24 & 20 & 19 & 18 & 16 & 18 & 24 & 20 & 22 & 21 & 19 & 18 & 16 & 20 & 19 & 20 & 22 & 19 & 18 & 19 & 22 & 17 \\
\hline $\mathrm{Zn}$ & 131 & 167 & 181 & 154 & 138 & 162 & 111 & 106 & 130 & 97 & 134 & 118 & 120 & 143 & 121 & 235 & 92 & 134 & 167 & 127 & 111 & 109 & 113 & 96 & 106 & 105 \\
\hline $\mathrm{Cu}$ & 60 & 30 & 33 & 68 & 40 & 50 & 59 & 43 & 84 & 21 & 26 & 38 & 28 & 44 & 84 & 39 & 25 & ) & 65 & 65 & 62 & 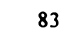 & 88 & 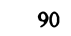 & 43 & 68 \\
\hline $\mathrm{Ni}$ & 5 & 45 & 75 & 21 & 10 & 29 & 27 & 85 & 45 & 106 & 6 & 55 & 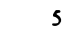 & 21 & 41 & 38 & 42 & 26 & 16 & 78 & 76 & 34 & 37 & 82 & 15 & 45 \\
\hline v & 371 & 216 & 258 & 381 & 419 & 444 & 440 & 301 & 279 & 261 & 85 & 254 & 153 & 536 & 374 & 273 & 160 & 430 & 372 & 318 & 323 & 417 & 428 & 183 & 437 & 304 \\
\hline $\mathrm{Cr}_{\mathrm{r}}$ & 13 & 112 & 132 & 80 & 31 & 66 & 58 & 38 & 191 & 216 & 11 & 136 & 19 & 34 & 125 & 144 & 144 & 40 & 36 & 17 & 196 & 75 & 75 & 141 & 37 & 219 \\
\hline Cs & 0.7 & 0.3 & 0.3 & 0. & 0.1 & 0.2 & 0 . & 0.6 & 0.9 & 2.4 & 1.2 & 0.6 & 0.6 & 0.8 & na & 2.4 & 7.7 & 1.2 & 2.0 & 1. & 2.5 & 1.1 & 1.1 & 1.2 & nd & 2.3 \\
\hline Hf & 4.0 & 8.0 & 5.4 & 4.5 & 7.0 & 4.8 & 4. & 4.2 & 2.9 & 2.5 & 7.9 & 3.3 & 6. & 5.0 & 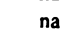 & 4.4 & 4.4 & 4.9 & 3.8 & 3. & 3.3 & 3.6 & 3.8 & 4.0 & 3.9 & 3.9 \\
\hline Ta & 0.4 & 0.2 & 0.5 & 0.3 & 0.8 & 0.5 & 0.4 & 0.5 & 0.3 & 0.1 & 0.8 & 0.4 & 0.7 & 0.4 & na & 0.3 & 0.3 & 0.4 & 0.4 & 0.3 & 0.4 & 0.3 & 0.3 & 0.4 & 0.5 & 0.4 \\
\hline U & 0.7 & 0.2 & 0.4 & 0.6 & 0.9 & 0.4 & 0.6 & nd & 0.1 & 0.1 & 0.3 & 0.2 & 0.7 & 0.2 & na & 0.5 & 0.8 & 0.3 & 0.4 & 0.3 & 0.3 & 0.4 & 0.3 & 0.2 & 0.3 & 0.4 \\
\hline Sc & 33.1 & 28.6 & 33.8 & 42.3 & 36.5 & 42.7 & 42.9 & 28.5 & 48.2 & 31.7 & 23.5 & 30.5 & 29.0 & 41.4 & na & 36.8 & 22.9 & 37.1 & 39.3 & 42.2 & 41.0 & 45.1 & 45.3 & 25.5 & 36.4 & 42.1 \\
\hline Co & 31.4 & 24.8 & 38.9 & 41.2 & 36.6 & 41.6 & 42. & 46.0 & 36.7 & 44.4 & 15.0 & 34.9 & 20.47 & 37.5 & па & 36.4 & 23.4 & 35.8 & 37.4 & 51.3 & & 3.6 & 44.8 & 35.6 & 34 & 39.9 \\
\hline La & 21.07 & 25.23 & 14.93 & 15.23 & 18.52 & 16.32 & 10.65 & 15.29 & 9.16 & 3.69 & 25.38 & 10.23 & 21.58 & 14.39 & na & 12.32 & 11.19 & 14.57 & 15.61 & 8.02 & 8.86 & 9.35 & 9.27 & 25.67 & 13.14 & 9.96 \\
\hline $\mathrm{Ce}$ & 55.22 & 64.72 & 40.84 & 39.85 & 49.26 & 42.22 & 27.79 & 32.32 & 24.22 & 12.58 & 65.51 & 28.49 & 56.18 & 36.51 & na & 32.78 & 28.60 & 37.77 & 38.24 & 22.89 & 22.83 & 25.23 & 25.85 & 62.34 & 34.24 & 26.27 \\
\hline $\mathrm{Nd}$ & 35.75 & 41.67 & 26.83 & 28.51 & 32.43 & 28.17 & 19.04 & 22.41 & 16.00 & 11.74 & 43.80 & 21.88 & 32.55 & 25.69 & na & 20.93 & 15.97 & 25.86 & 22.07 & 14.7 & 15.89 & 18.86 & 18.94 & 29.65 & 22.80 & 17.29 \\
\hline Sm & 8.53 & 9.81 & 6.88 & 7.53 & 8.66 & 6.87 & 5.73 & 6.86 & 4.72 & 3.66 & 11.01 & 5.53 & 9.53 & 7.13 & na & 5.58 & 4.32 & 7.02 & 5.96 & 4.80 & 4.74 & 5.40 & 5.47 & 6.13 & 6.39 & 5.03 \\
\hline Eu & 2.83 & 3.02 & 2.16 & 2.88 & 2.96 & 2.44 & 2.11 & 2.09 & 1.63 & 1.51 & 3.65 & 2.10 & 3.2 & 2.59 & na & 1.79 & 1.27 & 2.49 & 1.98 & 1.84 & 1.75 & 1.95 & 2.02 & 2.01 & 2.17 & 1.71 \\
\hline Tb & 1.61 & 1.91 & 1.40 & 1.38 & 1.6 & 1.21 & 1.1 & 1.2 & 0.89 & 0.76 & 2.02 & 1.05 & 1.71 & 1.40 & na & 1.06 & 0.79 & 1.28 & 1.05 & 0.93 & 0.89 & 1.16 & 1.20 & 0.92 & 1.29 & 0.96 \\
\hline $\mathrm{Yb}$ & 5.65 & 6.81 & 5.06 & 4.80 & 6.06 & 4.19 & 4.17 & 4.25 & 2.81 & 2.56 & 7.24 & 3.25 & 6.61 & 4.76 & na & 3.61 & 3.24 & 4.90 & 3.88 & 3.26 & 3.31 & 4.26 & 4.14 & 2.69 & 4.44 & 3.44 \\
\hline Lu & 0.83 & 0.98 & 0.73 & 0.70 & 0.85 & 0.57 & 0.57 & 0.66 & 0.42 & 0.35 & 1.04 & 0.45 & 0.91 & 0.66 & na & 0.52 & 0.47 & 0.69 & 0.56 & 0.46 & 0.47 & 0.63 & 0.63 & 0.40 & 0.64 & 0.50 \\
\hline
\end{tabular}

Notes: *All sample numbers are prefixed with letters $\mathrm{CM}$; $\mathrm{na}=$ not analyzed; $\mathrm{nd}=$ not detected 

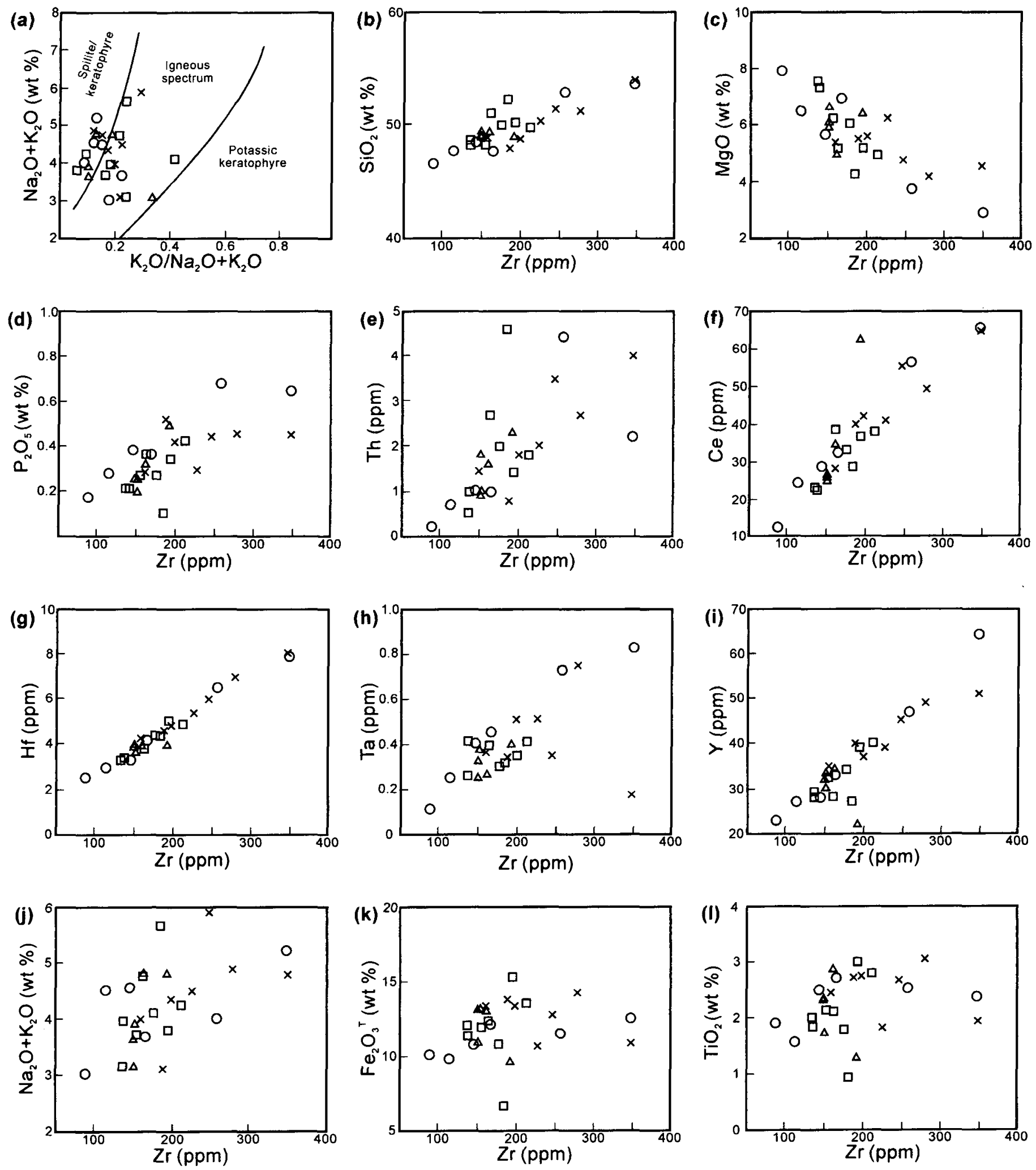

$$
\begin{array}{lllll|}
\hline x-N H F D & 0 & - \text { QFG } & - \text { QFD } & \Delta-\text { WBFI } \\
\hline
\end{array}
$$

Fig. 5. Binary chemical variation diagrams of the mafic intrusions. (a), spilite-keratophyre plot with fields after Hughes (1973); (b) to (l), diagrams illustrating relative mobility of selected elements. 
(a)
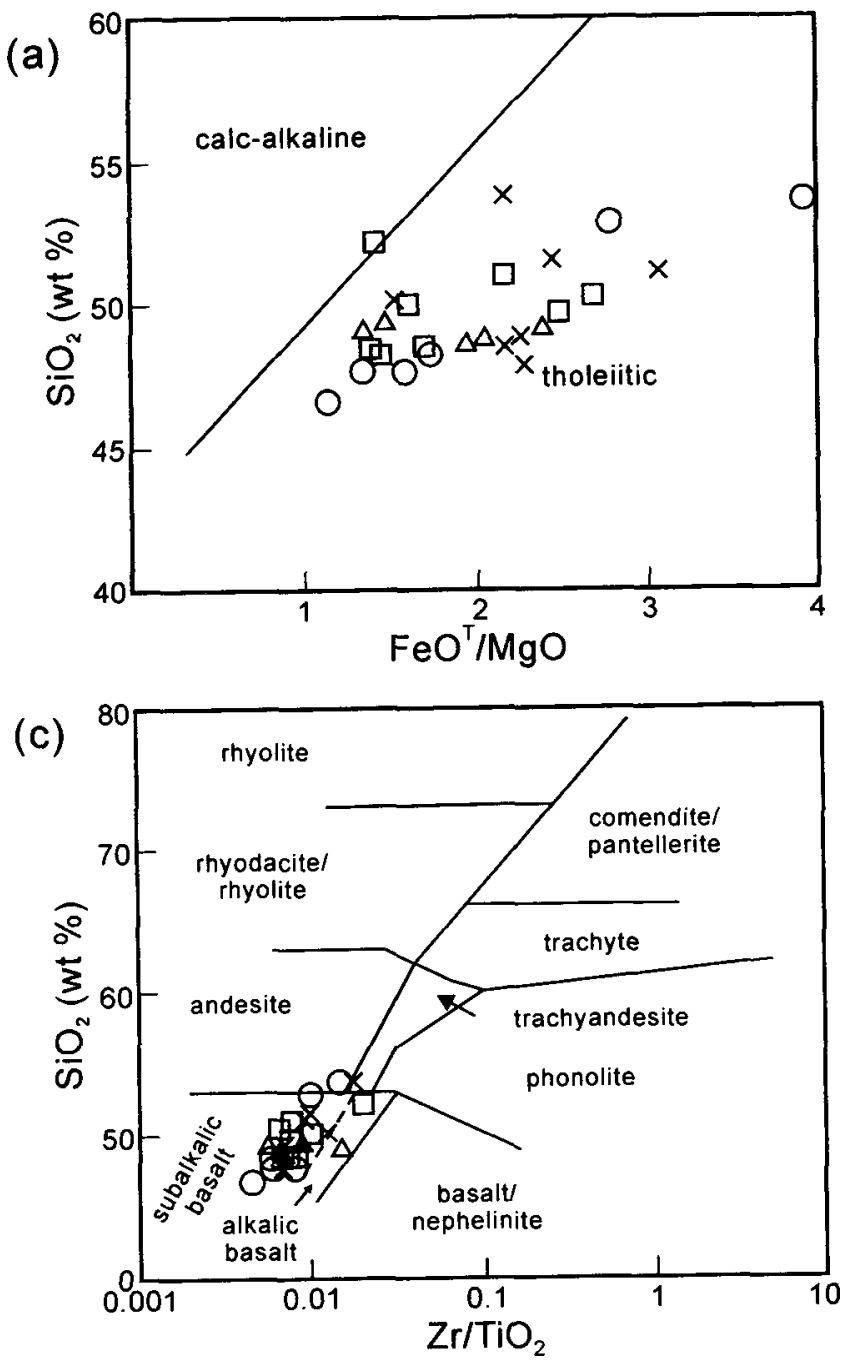

(b)

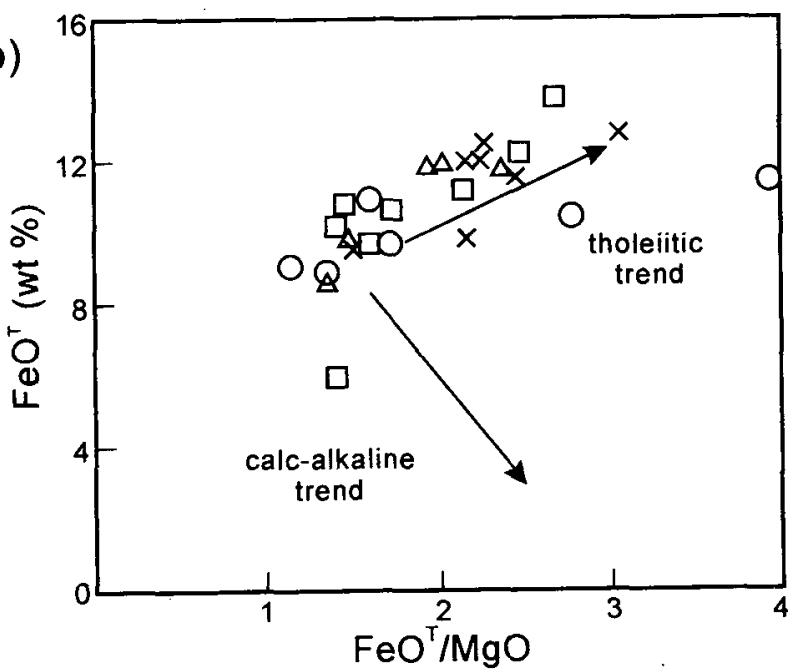

(d)

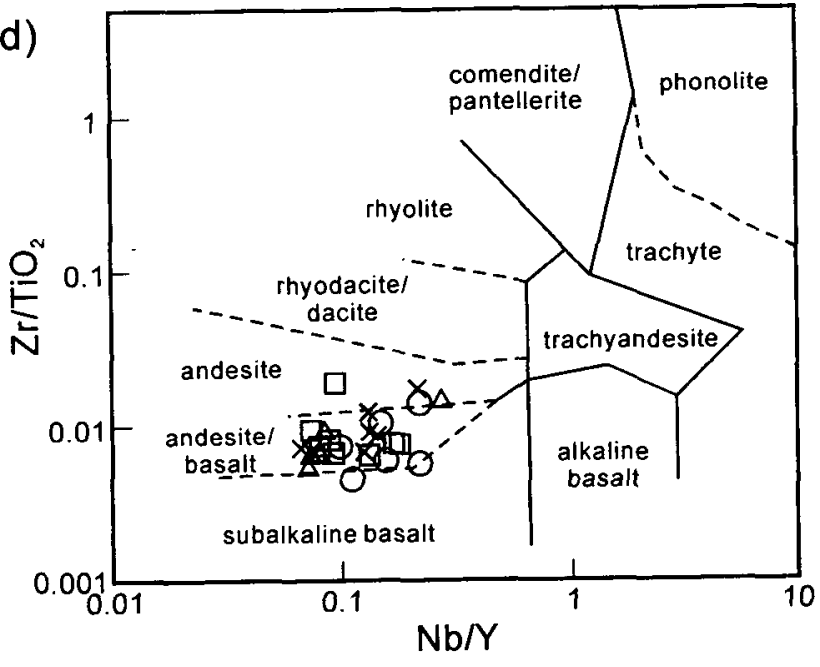

$$
\begin{array}{|lllll}
x-N H F D & 0 & -Q F G \quad \square & - \text { QFD } & \Delta-\text { WBFI }
\end{array}
$$

Fig. 6. Geochemical classification discrimination diagrams for the mafic intrusions. (a) and (b), fields and trends after Miyashiro (1974); (c) and (d), fields after Winchester and Floyd (1977).

shown for dykes in the Kingston Group on mainland New Brunswick and in Maine (Fig. 9e), which are also similar to the profiles from Campobello Island.

Cullers and Graf (1984) tabulated ranges of REE ratios and $\mathrm{REE}^{\mathrm{T}}$ for common mafic igneous rocks of the continental crust in a variety of tectonic settings, and discuss petrogenetic implications of REE variations in these rocks. In comparing their data with those from Campobello Island, the ratios and $\operatorname{REE}^{\mathrm{T}}$ concentrations are consistent with values found for tholeiitic intrusive complexes and, to some extent, for other continental tholeiitic rocks. Cullers and Graf (1984) also discussed the fact that large degrees of partial melting of enriched peridotite are required to produce these REEenriched magmas, that overall REE content can increase with fractionation of such minerals as olivine and pyroxene, and that negative $\mathrm{Eu}$ anomalies are produced by plagioclase fractionation.
The spread in REE patterns exhibited within the main groups of intrusions, which is most pronounced in the QFG, could reflect periodic tapping of a fractionating magma chamber at depth. Based on major, minor, and limited trace element data, Dickson (1983) postulated that some fractionation of source magmas could be invoked to explain chemical variations in similar dykes on mainland New Brunswick. The lack of negative Eu anomalies precludes plagioclase being involved in the fractionation process. Overall contrasts in absolute REE abundances between some of the main groups of intrusions (cf., the NHFD and the QFD) may indicate chemical variability within the magma chamber in space and/or time, or the presence of more than one, genetically related chamber. The two anomalous profiles that exhibit LREE depleted and strongly LREE enriched profiles in the QFG and the WBFI respectively likely reflect more extreme, local perturbations in the composition of the chamber(s). 

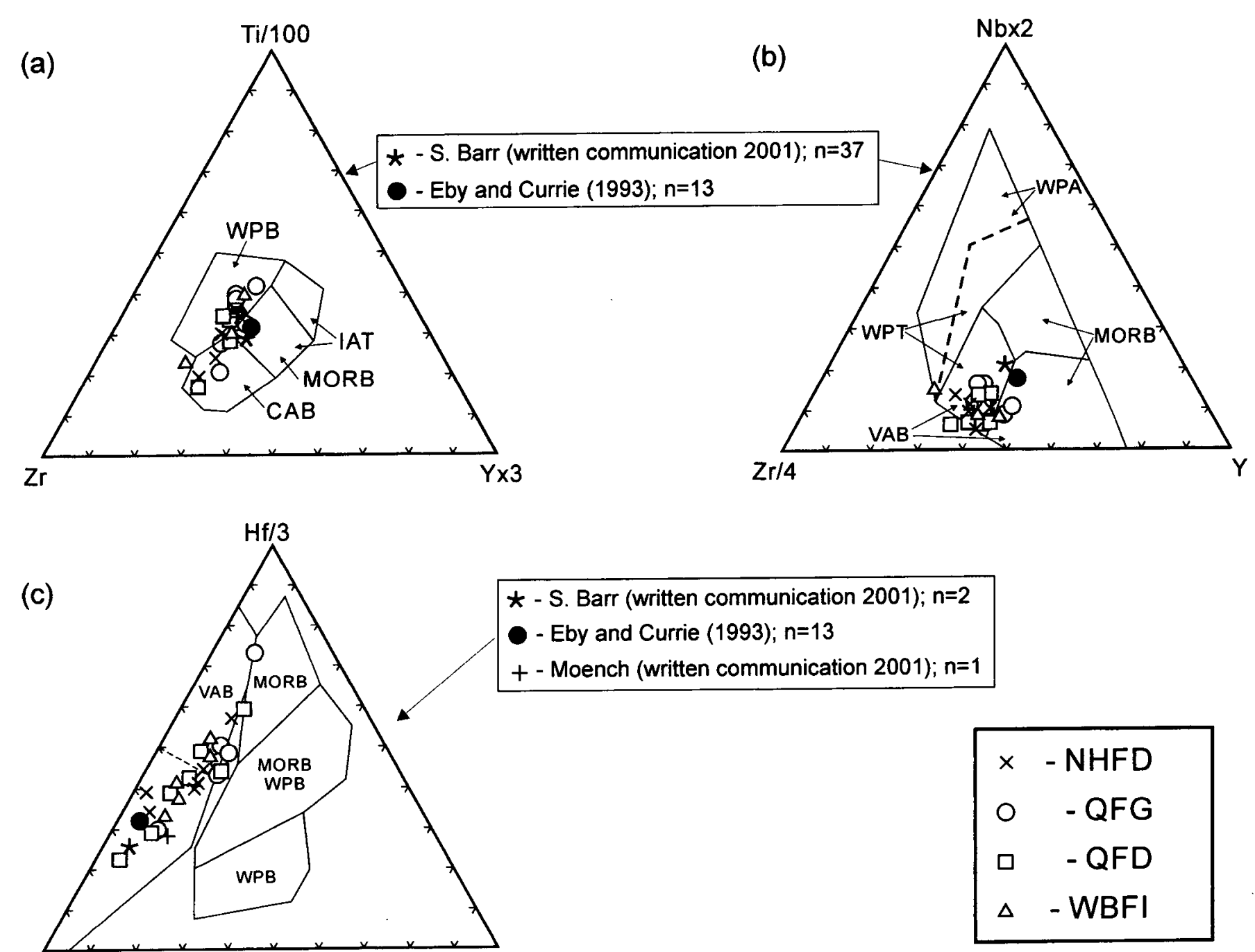

Th

Fig. 7. Tectonic setting discrimination diagrams for the mafic intrusions. (a), fields after Pearce and Cann (1973); (b), fields after Meschede (1986); (c), fields after Wood et al. (1979). Abbreviations: WPB = within-plate basalt; IAT = island-arc tholeiite; MORB = mid-ocean ridge basalt; $\mathrm{CAB}=$ calc-alkalic basalt; WPA $=$ within-plate alkalic basalt; WPT $=$ within-plate tholeiitic basalt; $\mathrm{VAB}=$ volcanic-arc basalt. Averages for similar intrusions along strike in New Brunswick (S. Barr, written communication 2001; Eby and Currie 1993) and Maine (R. Moench, written communication 2001).

Although crustal contamination of these types of magmas could be invoked to explain the enrichment of large ion lithophile elements like Th and LREE in the Campobello Island intrusions (e.g., Wilson 1989), bulk contamination by crustal materials in dyke swarms at deep crustal levels is typically insignificant (Mohr 1987). As the Campobello intrusions were emplaced into an arc-type volcanic pile, the scenario discussed by Tarney and Weaver (1987) for large ion lithophile elements and LREE enriched dyke swarms derived from already enriched mantle sources related to subduction processes is more likely. It is notable that their model also provides a mechanism to explain the inheritance of the negative Ta anomalies discussed above, and the subduction zone signature on the $\mathrm{Hf} / 3-\mathrm{Ta}$-Th diagram for the Campobello Island intrusions.
The averages of chemical analyses from other mafic dykes in the Kingston Group along strike that have been added to Figs. 7, 8 and 9, include information from R. Moench (written communication 2001) in Maine, and from Eby and Currie (1993) and S. Barr (written communication 2001) in mainland New Brunswick. Comparison of these averages with the Campobello Island intrusions indicates close correlation, except the latter appear slightly more continental in character on Fig. 7.

\section{${ }^{40} \mathrm{Ar} /{ }^{39}$ Ar dating}

Two samples were selected for ${ }^{40} \mathrm{Ar} /{ }^{39} \mathrm{Ar}$ dating: a schistose dyke in the Nancy Head Formation (CM47c2) and a dyke from the Quoddy Formation (CM138) (samples 4 and 18, Fig. 3). Amphibole separates were prepared by standard laboratory techniques and analyses were conducted at the 
(a).

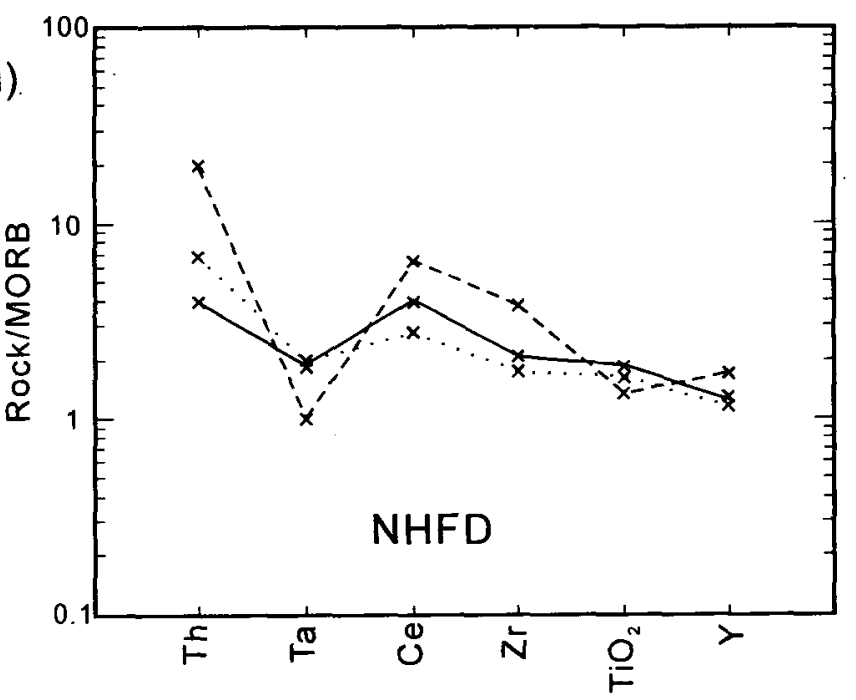

(c)

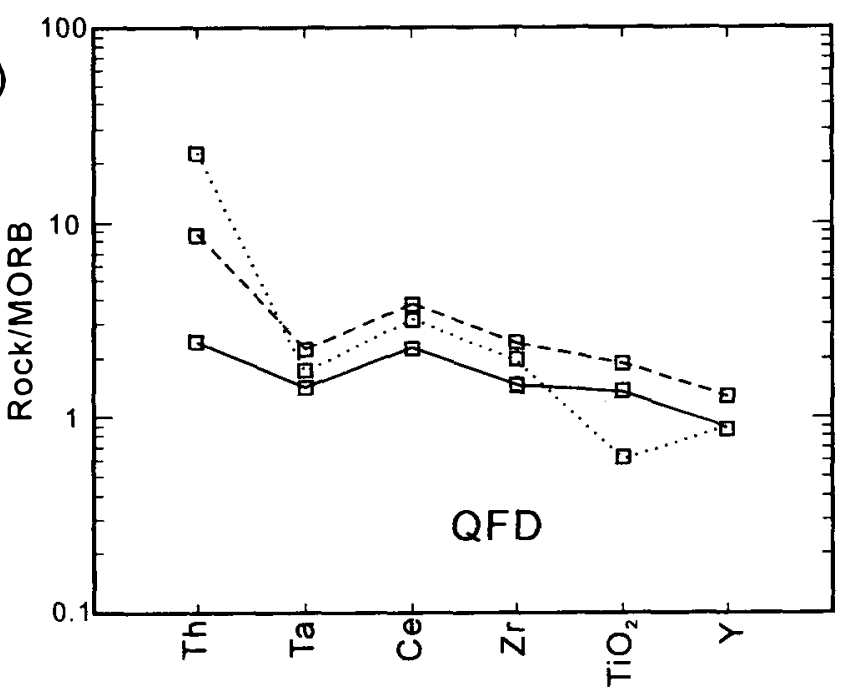

(b)

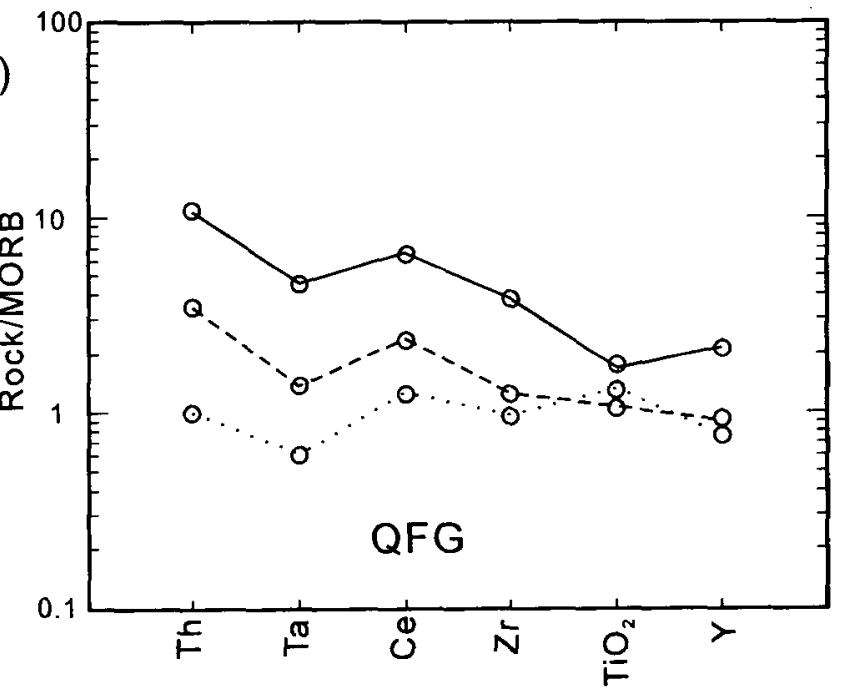

(d)

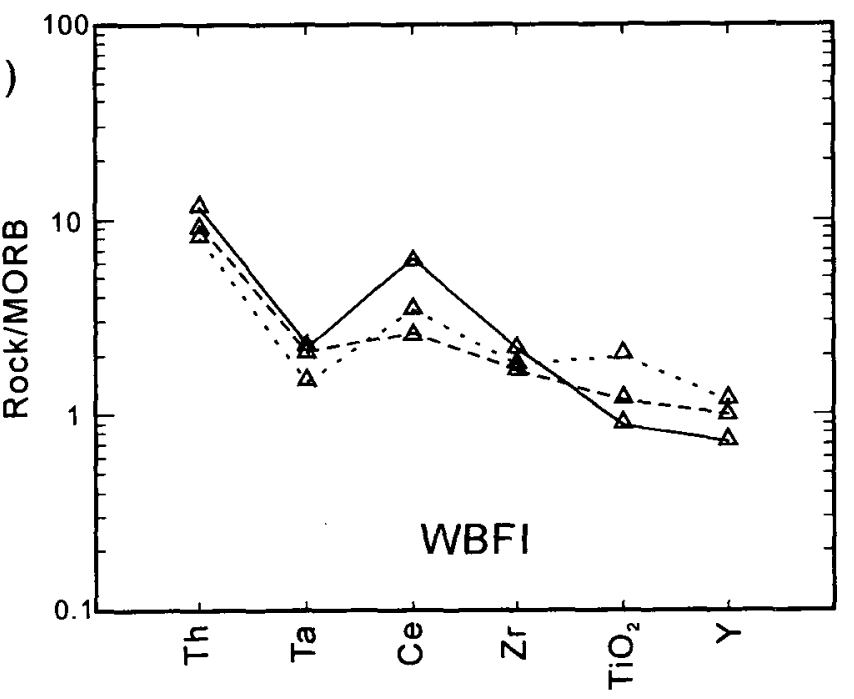

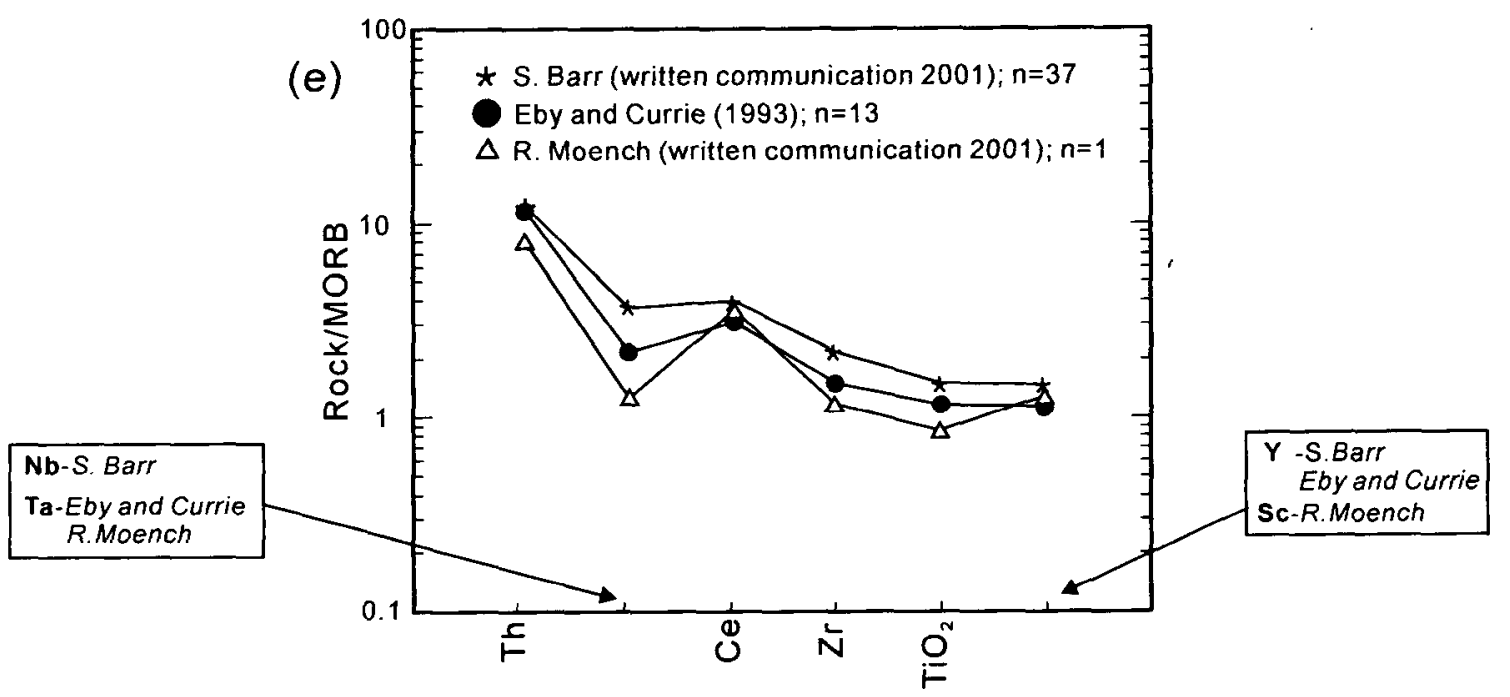

Fig. 8. Multi-element profiles of the mafic intrusions. (a), (b), (c) and (d), profiles for NHFD, QFG, QFD and WBFI respectively; (e), profiles for similar intrusions along strike in New Brunswick (S. Barr, written communication 2001; Eby and Currie 1993) and Maine (R. Moench. written communication 2001). 
(a)

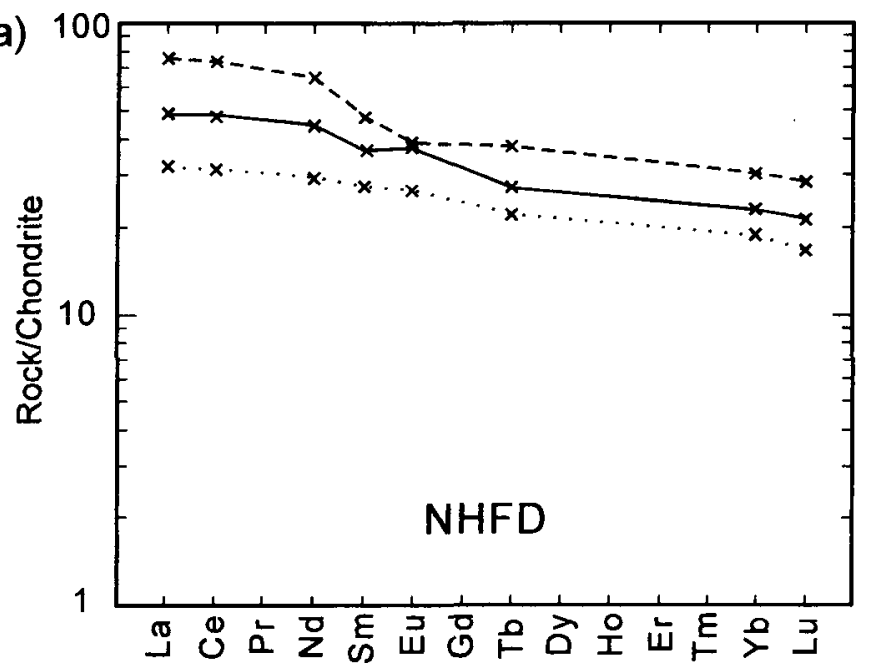

(c)

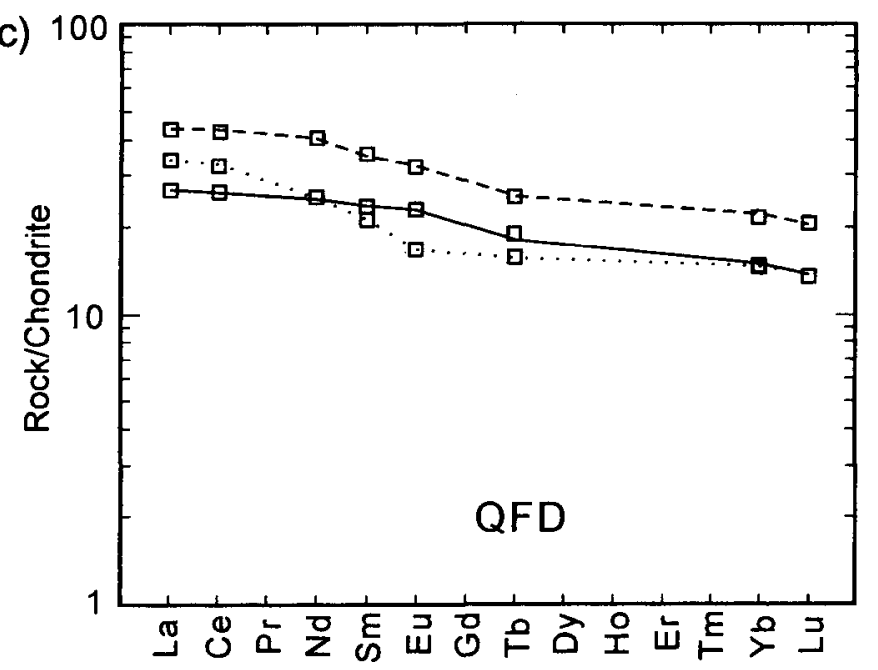

(e)

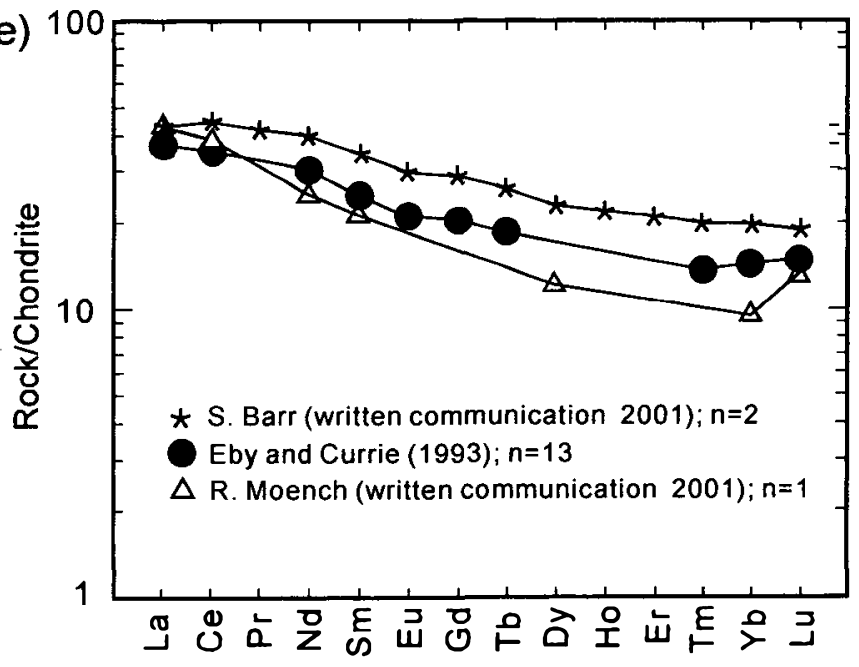

(b)

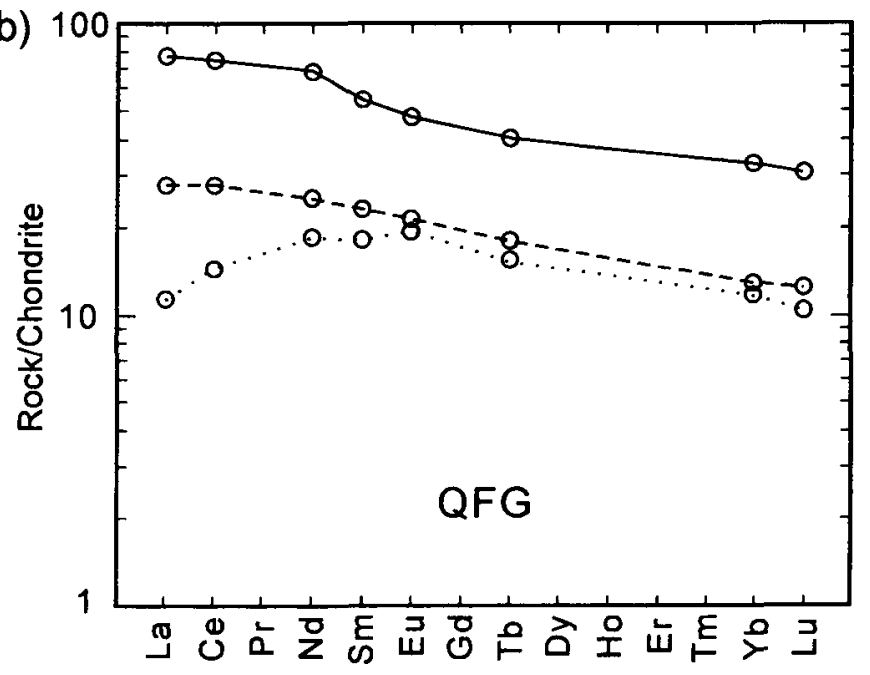

(d)

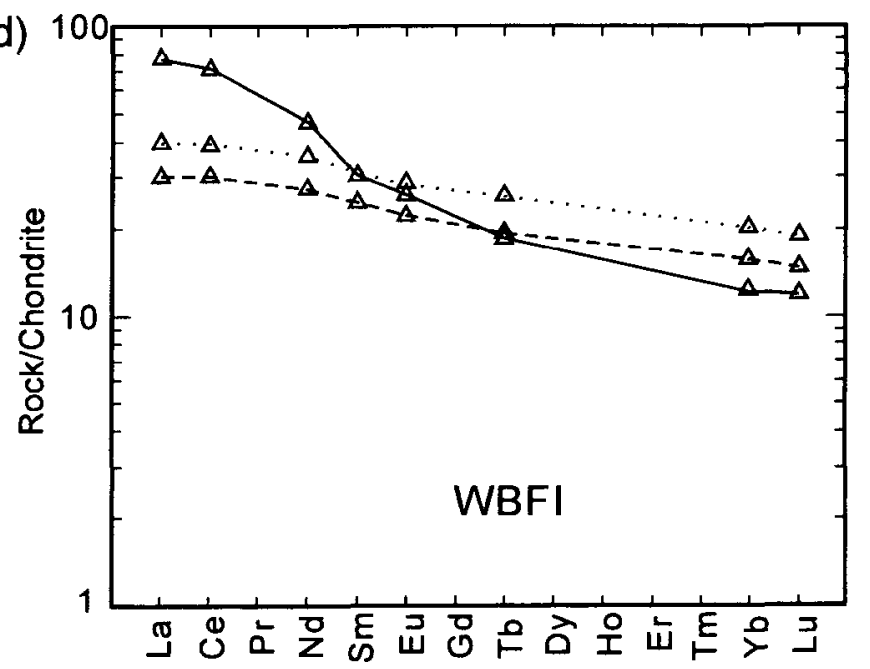

Fig. 9. REE plots for the mafic intrusions. (a), (b), (c) and (d), plots for NHFD, QFG, QFD and WBFI respectively. Normalizing factors after Nakamura (1974). Profiles for similar intrusions along strike in New Brunswick (S. Barr, written communication 2001; Eby and Currie 1993) and Maine (R. Moench, written communication 2001). 
Table 3: Argon release data.

\begin{tabular}{|c|c|c|c|c|c|c|c|c|}
\hline $\begin{array}{c}\mathrm{T} \\
\left({ }^{\circ} \mathrm{C}\right) \\
\end{array}$ & $\frac{{ }^{40} \mathrm{Ar}}{{ }^{39} \mathrm{Ar}}$ & $\begin{array}{l}{ }^{37} \mathrm{Ar} \\
{ }^{39} \mathrm{Ar}\end{array}$ & $\begin{array}{l}{ }^{36} \mathrm{Ar} \\
{ }^{39} \mathrm{Ar} \\
\end{array}$ & $\begin{array}{c}{ }^{39} \mathrm{Ar}^{*} \\
\text { (Moles) }\end{array}$ & $\%^{39} \mathrm{Ar}$ & $\%{ }^{40} \mathrm{Ar}^{\S}$ & $\frac{\mathrm{K}}{\mathrm{Ca}}$ & $\begin{array}{l}\text { Age } \\
(\mathrm{Ma}) \\
\end{array}$ \\
\hline \multicolumn{9}{|c|}{ Sample CM47C2; J=0.006138 } \\
\hline 650 & 102.74 & 1.877 & 0.2642 & 16.8 & 2.6 & 24.1 & 0.261 & $256.0 \pm 17.0$ \\
\hline 750 & 81.18 & 2.04 & 0.1696 & 21.6 & 3.4 & 38.4 & 0.24 & $316.6 \pm 11.1$ \\
\hline 820 & 69.51 & 2.578 & 0.121 & 24.8 & 3.9 & 48.9 & 0.19 & $342.2 \pm 23.2$ \\
\hline 880 & 59.45 & 3.66 & 0.0801 & 30.4 & 4.8 & 60.7 & 0.133 & $361.8 \pm 7.4$ \\
\hline 940 & 48.74 & 7.951 & 0.0373 & 60 & 9.4 & 78.8 & 0.061 & $383.9 \pm 4.5$ \\
\hline 1000 & 45.32 & 9.773 & 0.0243 & 88.8 & 14 & 86 & 0.05 & $389.8 \pm 3.6$ \\
\hline 1070 & 43.94 & 10.732 & 0.0181 & 112 & 17.6 & 89.9 & 0.045 & $394.7 \pm 3.7$ \\
\hline 1140 & 43.44 & 11.612 & 0.0176 & 121.6 & 19.1 & 90.3 & 0.042 & $392.5 \pm 3.6$ \\
\hline 1190 & 43.56 & 11.72 & 0.0172 & 97.6 & 15.4 & 90.6 & 0.041 & $394.7 \pm 3.8$ \\
\hline \multirow{3}{*}{$\begin{array}{r}\text { Fusion } \\
\text { Total }\end{array}$} & 44.52 & 11.692 & 0.02 & 61.6 & 9.7 & 89 & 0.042 & $395.8 \pm 5.3$ \\
\hline & & & & $\overline{635.2}$ & 100 & & & $382.7 \pm 5.5$ \\
\hline & & & & & & \multicolumn{2}{|c|}{ Plateau age } & $394.0 \pm 4.5$ \\
\hline \multicolumn{9}{|c|}{ Sample CM138; J=0.006083 } \\
\hline 680 & 61.71 & 0.48 & 0.1212 & 57.6 & 24.5 & 42 & 1.02 & $264.3 \pm 4.0$ \\
\hline 780 & 65.66 & 1.531 & 0.1298 & 34.4 & 14.6 & 41.7 & 0.32 & $278.5 \pm 7.0$ \\
\hline 840 & 63.2 & 4.877 & 0.1153 & 22.4 & 9.5 & 46.7 & 0.1 & $299.1 \pm 10.0$ \\
\hline 920 & 57.08 & 14.187 & 0.0727 & 27.2 & 11.6 & 64.5 & 0.034 & $368.4 \pm 12.0$ \\
\hline 1000 & 54.5 & 16.353 & 0.0574 & 24.8 & 10.5 & 71.5 & 0.03 & $388.1 \pm 13.9$ \\
\hline 1090 & 53.07 & 18.937 & 0.0509 & 33.6 & 14.3 & 74.8 & 0.025 & $395.3 \pm 6.9$ \\
\hline 1180 & 54.78 & 18.899 & 0.0549 & 20.8 & 8.8 & 73.4 & 0.026 & $399.9 \pm 8.7$ \\
\hline Fusion & 62.37 & 18.283 & 0.0815 & 14.4 & 6.1 & 63.9 & 0.026 & $396.8 \pm 1.9$ \\
\hline Total & & & & 235.2 & 100 & & & $333.6 \pm 8.3$ \\
\hline
\end{tabular}

(a)

$$
*=\times 10^{-13}, \S=\text { radiogenic }{ }^{40} \mathrm{Ar}
$$

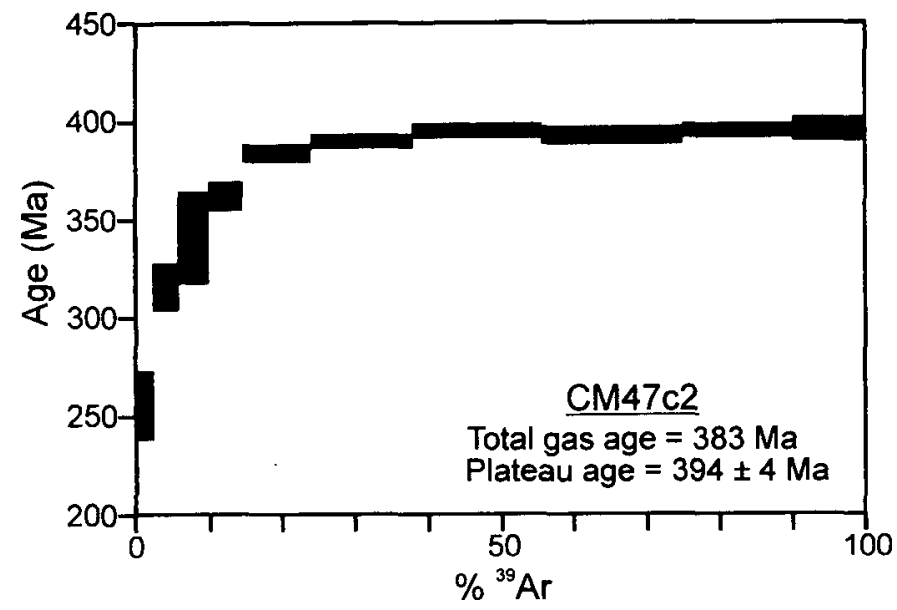

(b)

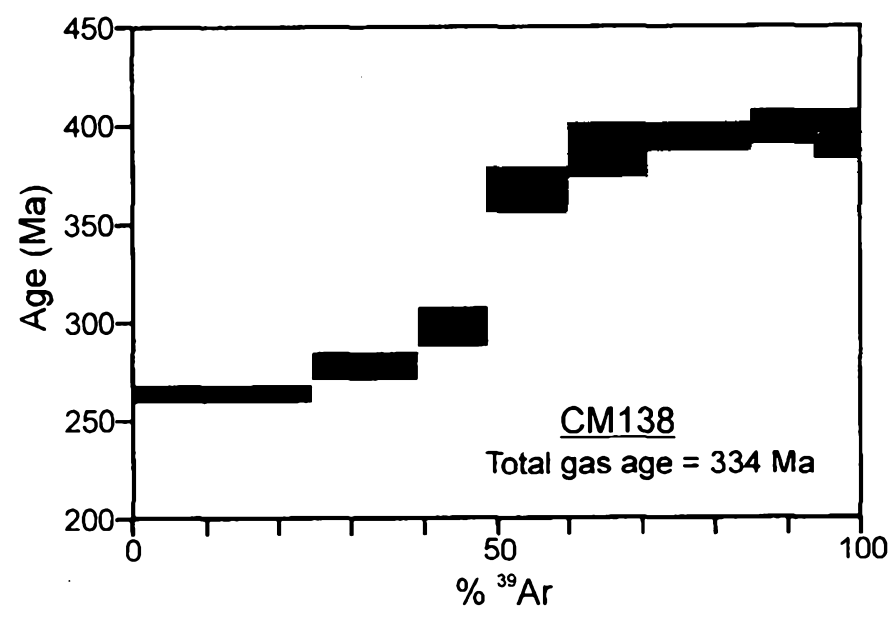

Fig. 10. Ar release spectra for amphiboles in samples CM47c2 and CM138.

University of Maine, Orono, Maine, following methods described by McLeod et al. (1988). Results of incremental heating experiments and the release spectra are given in Table 3 and Fig. 10. The release spectra for both samples are suggestive of episodic loss of radiogenic ${ }^{40} \mathrm{Ar}$ loss. Ideally, the age for the first increment of gas released from the samples should date the time of argon loss, and a plateau should date their original cooling age through the hornblende closure temperature.

Amphibole in sample CM47c2 is typical of amphibole from schistose dykes in the Nancy Head Formation in that it defines the well-developed fabric at lower amphibolite-facies metamorphism. Most amphibole grains are zoned, with medium green actinolitic cores and dark blue-green 
hornblende rims, and newly formed hornblende is present in the matrix. Analyses yield a well-defined plateau age of $394 \pm$ $4 \mathrm{Ma}$ for the metamorphism, which is at the boundary between the Early and Middle Devonian according to the Geological Time Chart of Okulitch (1999).

Amphibole in sample CM138 is similar to that in some other mafic intrusions in the Quoddy Formation, affected by lower amphibolite-facies metamorphism. Crystals exhibit pale to medium green actinolitic cores surrounded by narrow and distinct, medium blue green hornblende rims. Analyses do not define an ideal plateau. However, the last four increments contain about $40 \%$ of the total radiogenic ${ }^{40} \mathrm{Ar}$ in the sample, have the highest radiogenic ${ }^{40} \mathrm{Ar}$ yield, exhibit fairly constant $\mathrm{K} / \mathrm{Ca}$ ratios and agree within analytical uncertainties at an age of $395 \pm 10$. This is essentially the same age as the plateau for sample CM47c2, and similar to the youngest age (392.6 \pm 2.0$)$ reported by Nance and Dallmeyer (1993) for dykes in the Kingston Group on mainland New Brunswick using similar analytical methods.

\section{DISCUSSION}

\section{Timing of deformation and metamorphism}

In the foregoing, it is argued that the Quoddy Formation and underlying mainly felsic volcanic sequences, including the Nancy Head Formation, constitute a more or less continuous depositional sequence based on contact relationships and age assignments. Megascopic structural patterns on Campobello Island indicate that the felsic sequence plunges to the southwest beneath the Quoddy Formation. The abruptness of the disappearance of the Nancy Head Formation is accentuated by southwest-side-down throws along the Schooner Cove and Oak Bay faults, which expose progressively deeper levels in the stratigraphic section to the northeast (the Nancy Head Formation) and shallower levels of the section to the southwest (the Quoddy Formation). Compositional contrasts are also reflected in plutonic rocks intruding these formations that are, in part, essentially coeval and compositionally similar to the volcanic rocks in the host sequences. Granitoid rocks constitute a large part of the Kingston Group northeast of Campobello Island (Barr et al. 1997, 1999), whereas voluminous mafic rocks prevail in the Quoddy Formation to the southwest that, in general, represent a subvolcanic complex according to Gates and Moench (1981). These relationships suggest that initial felsic magmatism ceased with the onset of deposition of the Quoddy Formation and was eventually replaced by high-level mafic activity. The transition is accentuated by the mafic volcanichosted exhalite at the base of the Quoddy Formation on Campobello Island, which could reflect a brief hiatus in deposition. Some of the massive dykes stratigraphically below this horizon in the Nancy Head Formation and throughout the Kingston Group to the northeast could represent feeders for the mafic flows and sills of the overlying Quoddy Formation. Felsic intrusive rocks in the form of keratophyres are also reported in the extreme southwestern end of the Kingston belt in Maine by Gates (1961). He suggested that some of these may have been extrusive, but if so their stratigraphic position is unknown.

Mafic intrusions in the formations of Campobello Island, and in the remainder of the Kingston Group along strike in both directions, are nearly identical chemically. Comprehensive petrographic descriptions of the mafic intrusions in Maine (Gates 1961) indicate little variation in texture and metamorphism along strike to the southwest. General descriptions vary on mainland New Brunswick in reference to the details of deformation and metamorphic assemblages of the dykes northeast of Campobello Island, but for the most part are similar to those described herein (cf. Rast 1979; Dickson 1983; McCutcheon and Ruitenberg 1987; Currie 1988; Nance and Dallmeyer 1993; Schreckengost and Nance 1996; Barr et al. 1999). All are undoubtedly genetically related; however, differences in some aspects of structural and metamorphic histories, and in the mode of occurrence of the mafic intrusions, must be reconciled.

On mainland New Brunswick, all gradations between well-foliated dykes with steep linear fabrics and nonlineated massive varieties have been documented regionally (e.g., Cumming 1916; Helmstedt 1968; Rast 1979). Gates (1961), in describing relatively weak cataclastic fabrics in the Cutler Diabase in the Cutler area of Maine, also noted evidence of a steep lineation. Helmstedt (1968) attributed the presence or absence of fabric elements in these rocks to laterally compressive stresses and syn- to post-tectonic dyke emplacement during the Middle Devonian Acadian Orogeny. Further, he noted that deformed dykes containing amphibole with strongly preferred orientation belonged to wellequilibrated metamorphic assemblages, whereas more massive varieties with randomly oriented amphiboles were not completely recrystallized to peak metamorphic conditions. These factors led him to suggest that metamorphic recrystallisation took place in a gradually subsiding stress field and that deformation ceased prior to associated, but waning, metamorphism. He attributed the deformation to lateral northwest to southeast shortening and possible vertical extension during Late Silurian time. In contrast, Rast (1979) invoked episodic tensional and compressional states of stress related to doming to explain these variations in fabric development. He assumed that the Kingston Group was Neoproterozoic in age, that younger radiometric ages of amphibole dated by Helmstaedt (1968) represented a retrogressed reset age for metamorphism, and that similar dykes are absent in Phanerozoic rocks in the area. Consequently, he attributed deformation and metamorphism to Neoproterozoic tectonic events, perhaps related to the opening of lapetus. Schreckengost and Nance (1996), in their study of dykes and fabrics along selected traverses through the Kingston belt on mainland New Brunswick, suggested that sigmoidal variations in dyke orientations relative to bounding ductile shear zones of the belt are related to sinistral shear during Avalonian accretionary events during Early Silurian time. They further suggested that consistent clockwise rotations of dyke trends and mineral lineations (including hornblende or actinolite), which plunge steeply in the interior of the belt and rotate to more gentle plunges towards the margins, indicate later dextral shear conditions prevailed 
during the Late Silurian-Early Devonian related to docking of the outboard Meguma terrane to the south. Later detailed mapping (Barr et al. 1997, 1999) found no evidence for sigmoidal variations in dyke orientations or shallowly plunging lineations in what they consider parts of the Kingston belt.

Textural relationships between the earliest, schistose dykes and the later less deformed to massive dykes, and associated metamorphic contrasts of the Nancy Head Formation, are very similar to those described by Helmstaedt (1968) and Rast (1979). Mechanisms invoked by these authors, i.e., syn-tectonic to post-tectonic dyke injection or episodic deformation, seem applicable to the situation on Campobello Island. Relationships on Campobello Island allow further clarification concerning timing of dyke injection, deformation and metamorphism. The absence of penetratively deformed dykes in the Quoddy Formation indicates that the oldest dykes must have been initiated and deformed before its deposition. Gates $(1961,1977)$ demonstrated that some of the younger dykes were injected nearly contemporaneously with Quoddy Formation deposition and that a continuous supply of mafic magma was likely present to feed mafic volcanics throughout the Silurian section in Maine. The apparent rotation of bedding at some localities in the Nancy Head Formation adjacent to dykes could also indicate still earlier dyke injection, nearly coeval with its deposition.

The progressive metamorphic assemblages observed in the dykes in the Nancy Head and Quoddy formations, and the preponderance of well-equilibrated, higher-grade metamorphic assemblages in the oldest (most deformed) dykes north of the Schooner Cove Fault can readily be explained by considering that the present metamorphic assemblages are the result of a progressive contact metamorphic front generated by a rising mafic magma source superimposed on undeformed and previously deformed dykes. In addition the deeper vs. shallower crustal levels, that are exposed northeast and southwest of the Schooner Cove Fault, respectively, may play a role in accentuating the contrasts in metamorphic grades in the Nancy Head vs. Quoddy formations across the fault. Further afield in Maine, presumably at still shallower crustal levels, weakly deformed dykes are described but higher metamorphic grades are not present (Gates 1961). Although most deformation of the Siluro-Devonian rocks in the region has traditionally been ascribed to the Middle Devonian Acadian Orogeny (Helmstaedt 1968; Ruitenberg 1968; Donohoe 1978), Silurian orogenesis in some areas is now well documented in the region based on ${ }^{40} \mathrm{Ar} /{ }^{39} \mathrm{Ar}$ studies (West et al. 1992, 1995; Nance and Dallmeyer 1993). The older ages in the range of dates reported by West et al. (1995) (ca. 430 to $414 \mathrm{Ma}$ ) document regional deformation, which is closely timed to the age required for deformation of the early dykes in the Kingston Group. Younger dates reported here and by Nance and Dallmeyer (1993) of ca. 416 to $390 \mathrm{Ma}$, represent the latest metamorphic event to affect the Kingston Group, which was likely also associated with development of the main fabric in the Quoddy Formation. The younger dates are barely within error for the K/Ar date of $369 \pm 21$ Ma reported for metamorphic amphibole in the dykes at Beaver Harbour (Helmstaedt 1968).
In Maine, a similar source of mafic magma to that in the Kingston Group may have been responsible for mafic intrusions and flows in younger Silurian formations and the composition of these magmas did not change until Lower Devonian time when they became even more continental in character (Gates 1977; Gates and Moench 1981). The geochemistry of the mafic intrusions in the Late Silurian Wilsons Beach Formation on Campobello Island, which is similar to that in the Kingston Group, supports this interpretation. However, other features indicate emplacement in a contrasting environment. They include (1) the lack of dyke swarms comparable to those in the Nancy Head and Quoddy formations in the Wilsons Beach Formation and correlative units on Deer Island and the Mascarene Peninsula, (2) their distinctive shear-type fabric where developed, and (3) their overall lower grade of metamorphism. These features are consistent with contrasts between the Wilsons Beach Formation and the other formations on Campobello Island and indicate that it was geographically removed from the main centre(s) of mafic magmatism responsible for dyke swarm injection during Silurian time.

\section{Nature of basement}

Cumming (1966) established the presence of Kingston Group rocks on Campobello Island based partly on aeromagnetic signatures. The distinct zone of high aeromagnetic response characteristic of the Kingston Group on mainland New Brunswick (Bhattacharyya and Raychaudhuri 1967) continues to the northeastern part of the island and then dissipates gradually to the southwest (Geological Survey of Canada Aeromagnetic Map 773G). Fifteen representative samples of the main rock types on the island were collected for magnetic susceptibility measurements in an effort to explain the aeromagnetic trends. Averages determined in $1 \times 10^{-3}$ SI units are as follows: Nancy Head Formation felsic volcanic rocks $=0.16$, schistose amphibolite dykes $=0.86$, massive diabase dykes $=1.96$; Quoddy Formation sandstones $=1.94$, shales $=0.27$, massive diabase dykes $=1.35$, gabbro intrusions $=1.10$; Wilsons Beach Formation gabbro intrusions $=0.86$. Overall, these susceptibilities are relatively low indicating that the high response of the belt on Campobello Island may not be generated by the mafic intrusions as previously assumed (e.g., Bhattacharyya and Raychaudhuri 1967). However, exposed Neoproterozoic rocks of the New River belt in the region have zones with high magnetic signatures and it is suggested that the magnetic signature in the Kingston belt of Campobello Island is generated by basement rocks of the New River belt (Geological Survey of Canada Aeromagnetic Map 596G). This interpretation implies that basement beneath the Nancy Head Formation could be relatively shallow. This and the dissipation of the high signatures to the southwest in the belt are consistent with the increased thickness of the Silurian section in that direction. The application of these aeromagnetic interpretations for the remainder of the Kingston belt in New Brunswick is the subject of ongoing research by others.

Basement to the Kingston Group is uncertain in that the base of the section is not exposed and contacts are faults that 
juxtapose the group against the New River and Caledonia belts to the northwest and the Brookville belt to the southeast on mainland New Brunswick, as defined by Johnson (2001). Based on field evidence, no unequivocal link can be made between these belts before mid-Paleozoic time (Johnson and McLeod 1996), although Fyffe et al. (1999) considered the New River and Brookville belts to be an entity throughout Cambrian to Early Silurian time. These authors depict the Caledonia belt of Barr and White (1989) to the south as separate during this time. U-Pb provenance studies of midSilurian conglomerate within the sequence indicate amalgamation of all Neoproterozoic blocks, including the Caledonia belt, prior to conglomerate deposition (Fyffe et al. 2001). In contrast, a tentative model based on $\mathrm{Nd}, \mathrm{O}$ and $\mathrm{Pb}$ isotopes was presented by Whalen et al. (1994), wherein all Late Neoproterozoic terranes in southern New Brunswick could have been amalgamated in Neoproterozoic time. Interpretations based on additional $\mathrm{Nd}$ isotopic data from southern New Brunswick presented by Samson et al. (2000) suggest that the New River and Brookville belts are actually parts of a single belt. They further suggest that limited data from the Kingston belt indicate a basement more similar to the Caledonia belt than to others in the region.

An indirect link to underlying basement rocks is provided by massive and schistose amphibolitic dykes that intrude the Neoproterozoic granites of the Pull and Be Damned Complex as described by Currie (1988). The complex is considered part of the New River belt (Johnson and McLeod 1996) and is the only other unit in the Passamaquoddy Bay region that contains a dyke swarm like that in the Kingston belt. Currie (1988) suggested that the schistose dykes are correlatives of those in the Kingston belt. Here, it is proposed that the entire swarm could be correlative and could underlie arc rocks of the Head Harbour Passage tract directly along strike to the southwest. This could be similar to the situation in the preceding discussion for the dykes on Campobello Island and lends support for assignment of the Head Harbour Passage tract to the Kingston Group. If true, then the Kingston Group is linked, in whole or part, to the New River belt.

\section{Conclusions}

Two units representing principal components of the Early Silurian Kingston belt, the Nancy Head and Quoddy formations, are exposed on Campobello Island. The former contains products of felsic magmatism and the later contains mafic volcanic and sedimentary rocks indicative of the Kingston Group on mainland New Brunswick and Maine respectively. A faulted segment of a younger part of the Silurian sequence deposited behind the arc, represented by the Wilsons Beach Formation, is also present on the island. Stratigraphic relationships, regional structural patterns, and aeromagnetic signatures indicate that the Nancy Head Formation conformably underlies the Quoddy Formation and plunges shallowly beneath the Quoddy Formation to the southwest. These formations represent a more-or-less continuous sequence and record a rapid transition from shallow water to subaerial to deeper water depositional environments.

The mode of occurrence and contrasts in deformation and metamorphism of mafic dyke swarms that intrude the Nancy Head and Quoddy formations indicate episodic dyke injection and deformation, and progressive metamorphism in the Kingston belt during Siluro-Devonian time. Earliest (Early Silurian) dykes injected prior to deposition of the Quoddy Formation are deformed, whereas those intruded later exhibit no penetrative fabrics. Metamorphic assemblages, which are highest in the deeper parts of the succession and attained lower amphibolite grade, appear to have been generated in a metamorphic front generated by a rising mafic magma source during mid-Devonian time.

The chemistry of the mafic intrusions on Campobello Island is uniform in that they all exhibit overall continental tholeiitic chemistry with strong arc-type signatures. They are interpreted to be representative of magmas generated at depth and tapped by deep penetrating fractures within a developing continental arc and emplaced during episodic periods of rifting (transtension?) within the arc.

As modelled by McLeod and Rast (1988) and reinforced by the work of Fyffe et al. (1999), the Kingston Group, including the Nancy Head and Quoddy formations on Campobello Island and their correlatives, form a narrow continuous, fault-bounded belt that is exposed from the Kingston Peninsula in New Brunswick to Cutler, Maine. It is also evident that the fault-bounded belt containing the Simpsons Island and Goss Point formations likely formed part of the group prior to offset along bounding faults. Furthermore, the faulted unit immediately northwest of the Quoddy formation in Maine may be a direct correlative of the Simpsons Island Formation. The integrity of the major lithotectonic belts to the north remains largely as previously established. The Mascarene belt has no direct correlatives in Maine, and the remainder of the Silurian to Early Devonian sequence crosses the international border and can be assigned to the Ovenhead belt including the Waweig and Oak Bay formations north of the Saint George Batholith. These correlations have important ramifications in the region for gold and base metal sulphide exploration, as important deposits have been discovered on both sides of the border.

The authors support the contention that there is overwhelming evidence for the existence of a Late Ordovician to Early Silurian arc (Johnson and McLeod 1996; Barr et al. 1999) above a northwesterly-dipping subduction zone (Fyffe et al. 1999) represented by the Kingston belt and correlative rocks in the Passamaquoddy Bay area. Although meagre at present, available chemistry of the volcanic sequences in the Mascarene Group is consistent with formation of constituents in a marginal basin northwest of the arc (Fyffe et al. 1999). If all Late Neoproterozoic terranes were amalgamated by Late Ordovician time or before, the proposed model would necessitate splitting of the continental block, formation of an ocean basin, and closure by the proposed subduction zone. Where this split would have occurred to form the hypothetical ocean needs to be resolved. Based solely on the possible cover/basement relationships described above and the present distribution of units, the ocean basin could have been between 
the Brookville and New River belts as defined at the presentday erosional surface.

\section{ACKNOWLEDGEMENTS}

The authors wish to extend their appreciation to Sandra Barr, Les Fyffe, Susan Johnson, Peter Stringer and Chris White for numerous enlightening discussions regarding the geology of the Kingston belt and the Passamaquoddy Bay area. We are grateful to Sandra Barr and Robert Moench for unpublished geochemical information from their work on mafic intrusions in the region, and Les Fyffe and Peter Stringer for providing useful comments that greatly improved the content of the paper. The paper also benefited from constructive comments by reviewers Damian Nance and John Greenough. Douglas Hall and David West are thanked for providing the SEM analyses and helping with the argon analyses, respectively. Maurice Mazerolle is thanked for his technical support.

\section{REFERENCES}

Alcock, F.J. 1938. Geology of Saint John region, New Brunswick. Geological Survey of Canada, Memoir 216, 65p.

AlcocK, F.J. 1949. Geological map of the Maritime Provinces. Geological Survey of Canada, Map 910A (with marginal notes).

BALDWIN, D.K. 1991. Physical volcanology, geochemistry, and depositional setting of Siluro-Devonian volcanic rocks near St. Andrews, New Brunswick. Unpublished M.Sc. thesis, Acadia University, Wolfville, Nova Scotia, $231 \mathrm{p}$.

BARR, S.M., \& WHITE, C.E. 1989. Re-interpretation of Precambrian stratigraphy, Kings and Saint John counties, New Brunswick. In Project Summaries for 1989, Fourteenth Annual Review of Activities. Edited by S.A. Abbott. New Brunswick Department of Natural Resources and Energy, Minerals and Energy Division, Information Circular 89-2, pp. 181-189.

BARR, S.M., \& WhITE, C.E. 2001. The Kingston Group: A redefined Silurian stratigraphic unit in southern New Brunswick. In Current Research 2000. Compiled by B.M.W. Carroll. New Brunswick Department of Natural Resources and Energy, Minerals and Energy Division, Mineral Resource Report 2001-4, pp. 1-14.

BARR, S.M., WHITE, C.E., \& MCLEOD, M.J. 1997. Geology of the Kingston Peninsula, southern new Brunswick: a preliminary report. In Current Research 1996. Edited by B.M.W. Carroll. New Brunswick Department of Natural Resources and Energy, Minerals and Energy Division, Mineral Resources Report, 97-4, pp. 1-20.

BARR, S.M., WhITE, C.E., \& MCLEOD, M.J. 1999. Geology of the Silurian Kingston Terrane, southern New Brunswick. In Current Research 1998. Edited by B.M.W. Carroll. New Brunswick Department of Natural Resources and Energy, Minerals and Energy Division, Mineral Resources Report, 99-4, pp. 1-17.

BERRY, W.B.N., \& BOUCOT, A.J. 1970. Correlation of the North American Silurian rocks. Geological Society of America, Special Paper 102, $289 \mathrm{p}$.

BERRY, H.N., \& OSBERG, P.H. 1989. A stratigraphic synthesis of eastern Maine and western New Brunswick. In Studies in Maine Geology. Edited by R.D. Tucker and R.G. Marvinney. Maine Geological Survey, Department of Conservation, Volume 2: Structure and Stratigraphy, pp. 1-32.

BASTIN, E.S., \& WILliaMS, H.S., 1914. Eastport Folio, Maine. United States Geological Survey, Folio 192, 15p.
Bhattacharyya, G.K., \& RaychaudhuRI, B. 1967. Aeromagnetic and geological interpretations of a section of the Appalachian Belt in Canada. Canadian Journal of Earth Sciences, 4, pp. 1015-1037.

CULLERS, R.L., \& GRAF, J.L. 1984. Rare earth elements in igneous rocks of the continental crust: predominantly basic and ultrabasic rocks. In Rare Earth Element Geochemistry. Edited by P. Henderson. Elsevier, Amsterdam, pp. 237-274.

CUMmING, C.L. 1916. The igneous rocks of Saint John, New Brunswick. Unpublished Ph.D. thesis, Princeton University, Princeton, New Jersey, $344 \mathrm{p}$.

CUMmING, L.M. 1966. Geology of the Passamaquoddy Bay region, Charlotte County, New Brunswick. Geological Survey of Canada, Paper 65-29, 36 p.

CURRIE, K.L. 1988. Saint George map area: the end of the Avalon zone in southern New Brunswick. In Current Research, Part B. Geological Survey of Canada, Paper 88-1B, pp. 9-16.

CURRIE, K.L. \& MCNICOLL, V.J. 1999. New data on the age and geographic distribution of Neoproterozoic plutons near Saint John, New Brunswick. Atlantic Geology, 35, pp. 157-166.

DiCKSON, W.L. 1983. Geology, geochemistry and petrology of the Precambrian and Carboniferous igneous rocks between Saint John and Beaver Harbour, southern New Brunswick. Unpublished Ph.D. thesis, University of New Brunswick, Fredericton, New Brunswick, 409 p.

DoIG, R., NANCE, R.D., MurPhy, J.B., \& CASSEDAY, R.P. 1990. Evidence for Silurian sinistral accretion of Avalon composite terrane in Canada. Geological Society of London Journal, 147, pp. 927-930.

DONOHOE, H.V., JR. 1978. Analyses of structures in the St. George area, Charlotte County, New Brunswick. Unpublished Ph.D. thesis, University of New Brunswick, Fredericton, New Brunswick, $227 \mathrm{p}$.

DOSTAL, J., \& MCCuTCHEON, S.R. 1990. Geochemistry of Late Proterozoic basaltic rocks from southeastern New Brunswick, Canada. Precambrian Research, 47, pp. 83-98.

EBY, G.N., \& CURRIE, K.L. 1993. Petrology and geochemistry of the Kingston complex - a bimodal sheeted dyke suite in southern New Brunswick. Atlantic Geology, 29, pp. 121-135.

FYFFE, L.R., \& FRICKER, A. 1987. Tectonostratigraphic terrane analysis of New Brunswick. Maritime Sediments and Atlantic Geology, 23, pp. 113-123.

FYFFE, L.R., \& PICKERILL, R.K. 1993. Geochemistry of Upper Cambrian-Lower Ordovician black shale along a northeastern Appalachian transect. Geological Society of America Bulletin, 105, pp. 897-910.

Fyffe, L.R., Pickerill, R.K., \& StrInger, P. 1999. Stratigraphy, sedimentology and structure of the Oak Bay and Waweig formations, Mascarene Basin: implications for the paleotectonic evolution of southwestern New Brunswick. Atlantic Geology, 35, pp. 59-84.

FyfFE, L.R., MCNicoll, V., \& VAN STAAL, C. 2001. Provenance of detrital zircons from the Oak Bay conglomerate of southwestern New Brunswick (abstract). Atlantic Geoscience Society Colloquium and Annual General Meeting. Program and Abstracts volume, p. 15.

Gates, O. 1961. The geology of the Cutler and Moose River quadrangles, Washington County, Maine. Maine Geological Survey, Quadrangle Mapping Series No. 1, 67 p.

GATES, O. 1969. Lower Silurian-Lower Devonian volcanic rocks of New England coast and southern New Brunswick. In North Atlantic - Geology and Continental Drift. Edited by M. Kay. American Association of Petroleum Geologists, Memoir 12, pp. 484-503. 
GATES, O, 1975. Geological map and cross-sections of the Eastport Quadrangle, Maine. Maine Geological Survey, Geological Map Series GM-3.

GATES, O. 1977. Notes to accompany Geological Map Series GM-3, Washington County, Maine. Maine Geological Survey, 19 p.

Gates, O. 1984. Geologic map of the Passamaquoddy Bay area, Maine and New Brunswick. Maine Geological Survey, Department of Conservation, Open File No. 84-10.

GATES, O., \& MOENCH, R.H. 1981. Bimodal Silurian and Lower Devonian volcanic rock assemblages in the Machias-Eastport area, Maine. U.S. Geological Survey, Professional Paper 1184, 32 p.

HELMSTAEDT, H. 1968. Structural analysis of the Beaver Harbour area, Charlotte County, New Brunswick. Unpublished Ph.D. thesis, University of New Brunswick, Fredericton, New Brunswick, 196 p.

HugHES, C.J. 1973. Late Precambrian volcanic rocks of Avalon, Newfoundland - a spilite/keratophre province; recognition and implications. Canadian Journal of Earth Sciences, 10, pp. 272 282.

JOHNSON, S.C. 2001. Constraining geology in the Pocologan River and Long Reach areas: implications for the New River belt and correlations in southern New Brunswick and Maine. Atlantic Geology, 37, pp. 61-79

JohnSON, S.C., \& MCLEOD, M.J. 1996. The New River Belt: a unique segment along the western margin of the Avalon composite terrane, southern New Brunswick. Geological Society of America, Special Paper 304, pp. 149-164.

MACKENZIE, G.S. 1964. Geology, Hampstead, New Brunswick. Geological Survey of Canada, Map 114A, with marginal notes.

MCCUTCHEON, S.R., \& RUITENBERG, A.A. 1987. Geology and mineral deposits, Annidale-Nerepis area, New Brunswick. New Brunswick Department of Natural Resources and Energy, Mineral Resources Division, Memoir 2, 141 p.

MCLEOD, M.J. 1979. The geology of Campobello Island, southwestern New Brunswick. Unpublished M.Sc. thesis, University of New Brunswick, Fredericton, New Brunswick, 181 p.

MCLEOD, M.J. 1995. Bedrock geology and metallic mineral occurrences in the Letang - Head Harbour Passage area, Charlotte county, New Brunswick. In Current Research 1994. Compiled and edited by S.A.A. Merlini. New Brunswick Department of Natural Resources and Energy, Minerals and Energy Division, Miscellaneous Report 18, pp. 141-156.

MCLEOD, M.J. 1997. Redefinition of the Queen Brook Formation of scuthem New Brunswick and preliminary geochemistry. In Current Research 1996. Edited by B.M.W. Carroll. New Brunswick Department of Natural Resources and Energy, Minerals and Energy Division, Mineral Resources Report, 97-4, pp. 175-190.

MCLEOD, M.J., \& PICKERILL, R.K. 1999. Geology of the HampsteadBeulah area, southern New Brunswick. In Abstracts, 1999: 24 ${ }^{\text {th }}$ annual Review of Activities. Edited by B.M.W. Carroll. New Brunswick Department of Natural Resources and Energy, Minerals and Energy Division, Information Circular 99-3, p. 35.

MCLEOD, M.J., \& RAST, N. 1988. Correlations and fault systematics in the Passamaquoddy Bay area, southwestern New Brunswick. Maritime Sediments and Atlantic Geology, 24, pp. 289-300.

MCLEOD, M.J., TAYLOR, R.P., \& LUX, D.R. 1988. Geology, ${ }^{40} \mathrm{Ar} /{ }^{39} \mathrm{Ar}$ geochronology and Sn-W-Mo-bearing sheeted veins of the Mount Douglas Granite, southwestern New Brunswick. Canadian Mining and Metallurgical Bulletin, 81, pp. 70-77.

MCLEOD, M.J., JOHNSON, S.C., \& RUITENBERG, A.A. 1994. Geological map of southeastern New Brunswick. New Brunswick Department of Natural Resources and Energy, Mineral Resources, Map NR-6.
MESHEDE, M. 1986. A method of discriminating between different types of mid-ocean ridge basalts and continental tholeiites with the $\mathrm{Nb}-\mathrm{Zr}-\mathrm{Y}$ diagrams. Chemical Geology, 56, pp. 207-218.

MIYASHIRO, A 1974. Volcanic rock series in island arcs and active continental margins. American Journal of Science, 274, pp. 321 355.

MOHR, P.A. 1987. Crustal contamination in mafic sheets: a summary. In Mafic Dyke Swarms. Edited by H.C. Halls and W.F. Fahrig. Geological Association of Canada, Special Paper 34, pp. 75-80.

NANCE, R.D., \& DALLMEYER, R.D. 1993. ${ }^{40} \mathrm{Ar} /{ }^{39} \mathrm{Ar}$ ages from the Kingston Complex, New Brunswick: evidence for SilurianDevonian tectonothermal activity and implications for the accretion of the Avalon composite terrane. Journal of Geology, 101, pp. 375-388.

NaKamuRA, Y. 1974. Determination of REE, $\mathrm{Ba}, \mathrm{Fe}, \mathrm{Mg}, \mathrm{Na}$ and $\mathrm{K}$ in carbonaceous and ordinary chondrites. Geochimica et Cosmochimica Acta, 38, pp. 757-775.

NOWLAN, G.S., MCCRACKEN, A.D., \& MCLEOD, M.J. 1997. Tectonic and paleogeographic significance of Late Ordovician conodonts in the Canadian Appalachians. Canadian Journal of Earth Sciences, 32, pp. 1521-1537.

O'BRIEN, B.H. 1976. The geology of parts of the Coldbrook Group, southern New Brunswick. Unpublished M.Sc. thesis, University of New Brunswick, Fredericton, New Brunswick, 214 p.

OKulitCH, A.V. 1999. Geological Time Chart. The National Earth Science Series Geological Atlas. Supplement to Geolog, 29, Part 1.

PEARCE, J.A. 1996. A user's guide to basalt discrimination diagrams. In Trace Element Geochemistry of Volcanic Rocks: Applications for Massive Sulphide Exploration. Edited by D.A. Wyman. Geological Association of Canada, Short Course Notes, 12, pp. 79-113.

PEARCE, J.A., \& CANN, J.R. 1973. Tectonic setting of basic volcanic rocks using trace element analyses. Earth and Planetary Science Letters, 19, pp. 290-300.

PICKERILl, R.K., \& PAJARI, G.E., JR. 1976. The Eastport Formation (Lower Devonian) in the northern Passamaquoddy Bay area, southwest New Brunswick. Canadian Journal of Earth Sciences, 13, pp. 266-270.

PiCKERILL, R.K., PAJARI, G.E., \& DiCKSON, W.L. 1978. Geology of the Lower Devonian rocks of Passamaquoddy Bay, southwest New Brunswick. In Guidebook for Field Trips in Southeastern Maine and Southwestern New Brunswick. Edited by A. Ludman. 70th Annual Meeting New England Intercollegiate Geological Conference, Trip A-3, pp. 38-56.

RAST, N. 1979. Precambrian meta-diabases of southern New Brunswick - the opening of the Iapetus Ocean? Tectonophysics, 59, pp. 127137.

Rast, N., \& Dickson, W.L. 1982. The Pocologan mylonite zone. In Major Structural Zones and Faults of the Northern Appalachians. Edited by P. St-Julien and J. Belland. Geological Association of Canada, Special Paper 24, pp. 249-261.

RUITENBERG, A.A. 1968. Geology and mineral deposits, Passamaquoddy Bay area. New Brunswick Department of Natural Resources, Mineral Resources Branch, Report of Investigation 7, $47 \mathrm{p}$.

RUITENBERG, A.A., \& MCCutChEON, S.R. 1982. Acadian and Hercynian structural evolution of southern New Brunswick. In Major Structural Zones and Faults of the Northern Appalachians. Edited by P. St-Julien and J. Béland. Geological Association of Canada, Special Paper 24, IGCP Project 27, pp. 131-148.

SAMSON, S.D., BARR, S.M., \& WHITE, C.E. 2000. Nd isotopic characteristics of terranes within the "Avalon Zone", southern New Brunswick. Canadian Journal of Earth Sciences, 37, pp. 1039-1052. 
SCHRECKENGOST K. A., \& NANCE, R.D. 1996. Silurian-Devonian dextral reactivation near the inboard margin of the Avalon composite terrane: Kinematic evidence from the Kingston complex, southern New Brunswick, Canada. Geological Society of America, Special Paper 304, pp. 165-178.

TARNEY, J. \& WEAVER, B. L. 1987. Geochemistry and petrogenesis of Early Proterozoic dyke swarms. In Mafic Dyke Swarms. Edited by H. C. Halls and W. F. Fahrig. Geological Association of Canada, Special Paper 34, pp. 81-94.

ThOMAS, M.D., \& WiLLIS, C. 1989. Gravity modelling of the Saint George Batholith and adjacent terrane within the Appalachian Orogen, southern New Brunswick. Canadian Journal of Earth Sciences, 26, pp. 561-576.

Van Wagoner, N.A., DadD, K.A., Baldwin, D.K., \& McNeil, W. 1994. Physical volcanology, stratigraphy, and depositional setting of the Middle Paleozoic volcanic and sedimentary rocks of Passamaquoddy Bay, southwestern New Brunswick. Geological Survey of Canada, Paper 91-14, 46 p.

WEST, D.P. JR., LUDMAN, A., \& LUX, D.R. 1992. Silurian age for the Pocomoonshine gabbro-diorite, southeastern Maine and its regional tectonic implications. American Joumal of Science, 292, pp. 253-273.

WeST, D.P., JR., GuidotTI, C.V., \& LuX, D.R. 1995. Silurian orogenesis in the western Penobscot Bay region, Maine. Canadian Journal of Earth Sciences, 32, pp. 1845-1858.

WhALEN, J. B., JENNER, G.A., CURRIE, K.L., BARR, S.M., LONGSTAFFE, F.J., \& HEGNER, E. 1994. Geochemical and isotopic characteristics of granitoids of the Avalon Zone, southern New Brunswick: possible evidence for repeated delamination events. Journal of Geology, 102, pp. 269-282.

WILSON, M. 1989. Igneous Petrogenesis. Chapman and Hall, London, $466 \mathrm{p}$.
WINCHESTER, J.A., \& FLOYD, P.A. 1977. Geochemical discrimination of different magma series and their differentiation products using immobile elements. Chemical Geology, 20, pp. 325-343.

WOOD, D.A., JORON, J.L., \& TREUIL, M. 1979. A re-appraisal of the use of trace elements to classify and discriminate between magma series erupted in different tectonic settings. Earth and Planetary Science Letters, 45, pp. 326-336.

Editorial responsibility: Sandra M. Barr

\section{NOTE ADDED IN PROOF}

A recently acquired earliest Cambrian U-Pb date (B. Miller, written communication, 2002) for rhyolite from the Simpsons Island Formation has implications for some of the interpretations presented in this paper. The Cambrian date apparently negates the proposal in this paper that this arc-type, predominantly volcanic sequence northwest of Campobello Island in New Brunswick forms a Late Ordovician to Early Silurian part of the Kingston Group. More likely, it constitutes a segment of a Cambrian Arc (or arcs) developed within the New River belt. Also, the possibly correlative volcanic sequence in the fault-bounded tract northwest of the Lubec fault in Maine is likely Cambrian as well. Due to the intimate association of the Late Ordovician Goss Point Formation with the Pull and Be Damned Complex, which contains mafic dykes similar to those in the Kingston Group, the authors contend that this formation still could represent part of the Kingston Group in the Letang area. 